\title{
The Demand and Standing Requirements in Stockholder Derivative Actions
}

When a corporation is injured by insiders or outsiders, ${ }^{1}$ one or more shareholders may, in certain circumstances, bring a suit on behalf of the corporation to redress the harm. ${ }^{2}$ Historically, the stockholder derivative suit has been the principal weapon of minority shareholders to cure abuses within the corporation. ${ }^{3}$ There are obvious dangers, however, in allowing a minority of shareholders whose interests may be relatively small to bring an action on behalf of a corporation. The alleged cause of action may be without merit, or the costs of litigation coupled with the adverse effect on the business relationship between the corporation and the party to be sued may outweigh any recovery which could be gained. In these situations a suit will be contrary to the best interests of the corporation. The derivative suit may also be abused by the filing of "strike" or "blackmail" suits-actions commenced for their settlement value with no expectation of securing any recovery for the corporation. ${ }^{4}$

This comment will examine two of the limitations on shareholder derivative actions that courts and legislatures have fashioned to minimize these dangers and to preserve the principle of corporate law that the directors should govern a corporation: the requirement that the shareholders exhaust intracorporate remedies and the requirement that the shareholders establish standing to sue. ${ }^{5}$

1 There is no distinction between an injury to a corporation caused by third parties and one caused by its officers, directors, or stockholders. 12 W. FLETCHER, CYcLOPEDIA OR THE LAW of Private Corporations $\S 5850$, at 182 (rev. perm. ed. 1971).

2 Shareholders may not sue in their personal capacity for an injury to the corporation even though they have suffered a pecuniary loss caused by a decline in the value of their stock. If a shareholder suffers a direct injury, however, he may sue in his own right for his own benefit. The proper classification of a shareholder suit is often the subject of dispute. See Note, Distinguishing Between Direct and Derivative Shareholder Suits, 110 U. PA. L. RÈv. 1147 (1962). This comment focuses solely on derivative actions.

${ }^{3}$ See Dykstra, The Revival of the Derivative Suit, 116 U. PA. L. Rev. 74, 77-82 (1967) [hereinafter cited as Dykstra].

I Id. at 75.

s Other devices limiting the ability of shareholders to maintain a derivative action are state security-for-expenses statutes and the contemporaneous ownership requirement. See Dykstra, supra note 3, at 88-97. "Standing" in the context of derivative actions is not to be confused with its more traditional meaning as defining when an individual can challenge governmental action. As used in the present context, standing defines when minority shareholders can sue despite the opposition of the board of directors or a majority of the shareholders. Use of this term in the derivative action context can be traced to Hawes v. Oakland, 104 U.S. $450,462(1882)$. 
To exhaust intracorporate remedies, complaining shareholders must, before commencing suit, make demand on both the directors ${ }^{6}$ and the shareholders ${ }^{7}$ to pursue the claim, or demonstrate why making such demand would be futile. The demand requirement is presently codified in rule 23.1 of the Federal Rules of Civil Procedure. ${ }^{8}$ Compliance with the mandates of rule 23.1, however, does not automatically entitle shareholders to bring a derivative action. If the directors refuse to sue as demanded, their decision will be final unless the shareholders can demonstrate standing to sue by proving that the directors' decision was wrongful.' The standing of minority shareholders to sue may also be affected by a vote of a majority of the shareholders not to sue. ${ }^{10}$ The standing requirement, unlike the exhaustion requirement, is not embodied in the Federal Rules, but rather rests on the common law doctrine that minority shareholders should not be able to sue on behalf of their corporations against the will of the directors or a majority of the shareholders.

Although relatively straightforward in theory, the requirements of exhaustion of intracorporate remedies and standing to sue have been the subject of considerable confusion. This comment attempts to resolve the confusion and provide a workable framework for the courts.

\section{The Demand on Directors Requirement}

The requirement that demand be made on directors is embodied in rule 23.1 of the Federal Rules of Civil Procedure," which provides that shareholders must allege with "particularity" the efforts made to obtain the action they desire from directors or the reasons for not making an effort. Many states have laws or court rules containing similar provisions. ${ }^{12}$ This comment will analyze the judicial interpretation of the demand on directors requirement, the

\footnotetext{
- See text and notes at notes 13-90 infra.

7 See text and notes at notes 91-148 infra.

" Rule 23.1 states in relevant part:

In a derivative action brought by one or more shareholders or members to enforce a right of a corporation or of an unincorporated association, the corporation or association having failed to enforce a right which may properly be asserted by it, the complaint shall be verified and shall allege . . . with particularity the efforts, if any, made by the plaintiff to obtain the action he desires from the directors or comparable authority and, if necessary, from the shareholders or members, and the reasons for his failure to obtain the action or for not making the effort.

- See text and notes at notes $149-90$ infra.

10 See text and notes at notes 200-16 infra.

"For the text of rule 23.1, see note 8 supra.

12 E.g., Colo. R. Civ. P. 23.1; N.Y. Bus. Corp. LAW § 626(c) (McKinney 1963).
} 
purpose of the requirement, and finally what excuses should be sufficient to excuse a failure to make demand.

\section{A. The Demand on Directors Requirement and the Courts}

In surveying the cases that have interpreted the demand on directors requirement, Professor Moore has stated that "there is no unanimity of opinion amongst the courts, and probably the most straightforward approach is to admit frankly that it lies within the sound discretion of the court to determine the necessity for a demand." 13 This vague standard of "sound discretion" has led to inconsistent and confusing results because it has provided inadequate guidance to courts faced with the question of whether a demand on directors is necessary. ${ }^{14}$

At one extreme, the Fifth Circuit ${ }^{15}$ and several other courts ${ }^{16}$ have been very liberal in excusing plaintiffs from making demand on directors, interpreting the demand requirement in accordance with the flexible standards of modern notice pleading. ${ }^{17}$ The Tenth Circuit $^{18}$ has also taken a permissive attitude toward the demand on directors requirement. At the other extreme, the First Circuit ${ }^{19}$ has rejected the notice pleading interpretation, stating that rule 23.1 "is not an ordinary, but an exceptional rule of pleading, serving a special purpose, and requiring a different judicial approach."20 Other courts have followed this view. ${ }^{21}$ Much of the confusion surrounding the inconsistent application of the demand on directors requirement is attributable to a failure to understand the history and policies of the rule.

13 3B Moore's Federal Practice If 23.1.19, at 254 (2d ed. 1975). Many courts have accepted this summary of the law. E.g., Abbe v. Goss, 411 F. Supp. 923,924 (S.D.N.Y. 1975).

it The inconsistent state of the case law interpreting rule 23.1 has been acknowledged by the courts. See, e.g., DePinto v. Provident Security Life Ins. Co., 323 F.2d 826, 830 (9th Cir. 1963), cert. denied, 376 U.S. 950; Abbe v. Goss, 411 F. Supp. 923,924 (S.D.N.Y. 1975).

is Liboff v. Wolfson, 437 F.2d 121, 122 (5th Cir. 1971); Herpich v. Wallace, 430 F.2d 792, 817-18 (5th Cir. 1970).

"Jannes v. Microwave Communications, Inc., 57 F.R.D. 18, 21 (N.D. Ill. 1972); Barr v. Wackman, 36 N.Y.2d 371, 329 N.E.2d 180, 368 N.Y.S.2d 497 (1975).

17 See Fed. R. Civ. P. 8(a).

i* DeHaas v. Empire Petroleum Co., 286 F. Supp. 809 (D. Colo. 1968), aff'd, 435 F.2d 1223, 1228 (10th Cir. 1970). But see Meyers v. Keeler, 414 F. Supp. 935 (W.D. Okla. 1976).

19 In re Kauffman Mut. Fund Actions, 479 F.2d 257 (1st Cir.), cert. denied, 414 U.S. 857 (1973).

${ }^{20}$ Id. at 263.

${ }^{21}$ Brooks v. American Export Indus., Inc., 68 F.R.D. 506 (S.D.N.Y. 1975); Jones v. Equitable Life Assurance Soc'y, 409 F. Supp. 370 (S.D.N.Y. 1975); Kusner v. First Pa. Corp., 395 F. Supp. 276 (E.D. Pa. 1975); Phillips v. Bradford, 62 F.R.D. 681 (S.D.N.Y. 1974); Abrams v. Mayflower Investors, Inc., 62 F.R.D. 361 (N.D. Ill. 1974). 


\section{B. The Purpose of the Demand on Directors Requirement}

In the leading nineteenth-century case of Hawes $v$. Oakland, ${ }^{22}$ the Supreme Court stated that before a shareholder could institute a derivative action, he must

show to the satisfaction of the court that he has exhausted all the means within his reach to obtain, within the corporation itself, the redress of his grievances, or action in conformity with his wishes. He must make an earnest, not a simulated effort, with the managing body of the corporation, to induce remedial action on their part, and this must be made apparent to the court. ${ }^{23}$

The original purpose of the demand on directors requirement is clear: to prevent courts from interfering with the internal affairs of private corporations until all intracorporate remedies have been exhausted. ${ }^{24}$ Forcing shareholders to exhaust intracorporate remedies by first making demand on directors allows the directors a chance to occupy their usual status as managers of the corporation's affairs, giving the corporation an opportunity to take control of a suit that will be brought on its behalf. ${ }^{25}$ The demand requirement thus furthers a principle basic to corporate organization, that the management of the corporation be entrusted to its board of directors.

The demand requirement also has several practical advantages. Shareholders usually have little knowledge of the facts involved and lack access to the books and records of the corporation. Directors are generally familiar with the actions complained of and are therefore

${ }_{22} 104$ U.S. 450 (1882). The Court relied heavily on an earlier English case, Foss v. Harbottle, 67 Eng. Rep. 189, 2 Hare 461 (Ch. 1843).

${ }^{23}$ Hawes v. Oakland, 104 U.S. 450, 460-61 (1882). In 1882, the Supreme Court adopted Equity Rule 94 as a codification of the holding in Hawes. In 1912, the Court enacted Equity Rule 27, which modified the previous rule by adding the phrase "or the reasons for not making the effort." The change was prompted by the case of Delaware \& H. Co. v. Albany \& S.R.R., 213 U.S. 435 (1909), which held that demand could be excused if its exercise would be futile. Equity Rule 27 was adopted in the Federal Rules of Civil Procedure as rule 23(b). Rule 23.1, promulgated in 1966, substantially restates rule 23(b). Decisions prior to 1966 thus remain authoritative. C. WRIGHT, FEDERAL CourTs $\S 3$, at 318 (2d ed. 1970).

${ }^{24}$ For other early Supreme Court cases concerning the demand on directors requirement, see Wathen v. Jackson Oil Co., 235 U.S. 635 (1915); Delaware \& H. Co. v. Albany \& S.R.R., 213 U.S. 435 (1909); Doctor v. Harrington, 196 U.S. 579 (1905); Corbus v. Alaska Treadwell Gold Mining Co., 187 U.S. 455 (1903); Taylor v. Holmes, 127 U.S. 489 (1888); Quincy v. Steel, 120 U.S. 241 (1887); Dimpfell v. Ohio \& M. Ry., 110 U.S. 209 (1884).

${ }^{25}$ Delaware \& H. Co. v. Albany \& S.R.R., 213 U.S. 435, 446 (1909); Brody v. Chemical Bank, 517 F.2d 932, 934 (2d Cir. 1975); In re Kauffman Mut. Fund Actions, 479 F.2d 257, 263 (1st Cir.), cert. denied, 414 U.S. 857 (1973). 
in a better position to evaluate whether a claim is justified. ${ }^{26}$ The grievance may be resolvable without litigation, thus easing the burden on the courts. ${ }^{27}$ If litigation is appropriate, acceptance of the demand places the resources of the corporation, including its information, personnel, funds, and counsel, behind the suit. ${ }^{28}$ The directors, perhaps unlike derivative plaintiffs, have a fiduciary obligation to the corporation to act in its best interest in maintaining the action. ${ }^{29} \mathrm{In}$ addition, requiring demand as a condition precedent to a derivative action helps curtail the initiation of strike suits brought solely for their settlement value. ${ }^{30}$

The demand requirement also imposes little hardship on the complaining shareholders. The requirement can be satisfied by simply mailing a copy of the complaint to the board of directors advising them that unless the corporation enforces its rights, the shareholders will institute a derivative action against the alleged wrongdoer. ${ }^{31} \mathrm{~A}$ refusal should ordinarily have to be secured ${ }^{32}$ but a failure by the directors to act within a reasonable time should suffice to satisfy the demand requirement..$^{33}$ Once demand on the directors has been made and rejected, the exhaustion requirement of rule 23.1 is met and the rule does not bar a derivative action. ${ }^{34}$

${ }^{26}$ Brooks v. American Export Indus., Inc., 68 F.R.D. 506, 510 (S.D.N.Y. 1975); Abrams v. Mayflower Investors, Inc., 62 F.R.D. 361, 369 (N.D. Ill. 1974); Tasner v. Billera, 379 F. Supp. 815, 826 (N.D. Ill. 1974).

${ }^{27}$ Lerman v. ITB Management Corp., 58 F.R.D. 153, 158 (D. Mass. 1973); Baffino v. Bradford, 57 F.R.D. 79, 81 (D. Minn. 1972); Weiss v. Sunasco Inc., 316 F. Supp. 1197, 1206 (E.D. Pa. 1970).

${ }^{28}$ Note, Demand on Directors and Shareholders as a Prerequisite to a Derivative Suit, 73 HaRv. L. REv. 746, 749 (1960) [hereinafter cited as Demand on Directors].

20 Tasner v. Billera, 379 F. Supp. 815,826 (N.D. Ill. 1974). This same fiduciary duty will obligate the directors to pay heed to a meritorious shareholder demand. Id.

${ }^{30}$ Demand on Directors, supra note 28 , at 749 .

31 Tasner v. Billera, 379 F. Supp. 815, 825 (N.D. Ill. 1974).

32 Nussbacher v. Continental Ill. Nat'l Bank \& Trust Co., 518 F.2d 873, 877 (7th Cir. 1975), cert. denied, 424 U.S. 928 (1976).

${ }^{33}$ In Continental Sec. Co. v. Belmont, 206 N.Y. 7, 99 N.E. 138 (1912), for example, the plaintiff demanded in writing that the directors commence an action and gave the directors ten days to act upon the demand. When no action was taken within the time limit, the shareholder brought a derivative suit. The court held that the demand requirement was satisfied. Id. at 14-15, 99 N.E. at 141. But cf. Quincy v. Steel, 120 U.S. 241 (1887) (plaintiff not permitted to file suit thirteen days after making demand). In cases involving complex causes of action, directors should be given sufficient time to make a thorough investigation before a failure to act is allowed to satisfy the demand requirement.

is After demand has been made and rejected, courts should not impose overly formal pleading requirements since the shareholders have exhausted intracorporate remedies. But cf. Long v. Stites, 88 F.2d 554 (6th Cir.), cert. denied, 301 U.S. 706 (1937) (court held that the particularity requirement of rule 23.1 was not satisfied even though shareholders alleged that demand was made and rejected on a certain date, and subsequently a registered letter was sent to the directors notifying them that the suit would be instituted). Even if the 


\section{Excuses for Failing to Make Demand on Directors}

Given the advantages of the demand requirement and the ease of compliance, the shareholders should be required to make demand in almost every case. ${ }^{35}$ The proper standard for requiring demand should be that demand is necessary if there is any chance that the directors may take remedial action in response to the shareholders' complaint. ${ }^{36}$ This remedial action need not take the form of litigation; it is hoped that demand will foster informal resolution of differences. ${ }^{37} \mathrm{~A}$ failure to make demand should be excused only if requiring exhaustion would certainly be futile. The application and advantages of this standard can be demonstrated by examining several of the grounds that have been used to excuse demand.

1. Control. An argument frequently advanced by shareholders to excuse their failure to make demand is that demand would be futile because the directors are controlled by the alleged wrongdoers. ${ }^{38}$ Some courts have relied on this rationale to excuse a failure to make demand even though the complaining shareholders alleged no facts supporting their claim. ${ }^{39}$ In the early case of Doctor $v$. Harrington, ${ }^{40}$ for example, the Supreme Court held that an allegation that a wrongdoer controlled the directors, without any facts demonstrating how this control was obtained or exerted, was nonetheless sufficient to excuse demand. ${ }^{41}$ The more recent case of $d e$ Haas v. Empire Petroleum Co. ${ }^{42}$ also illustrates a tendency to excuse demand on the basis of questionable allegations of control. Two members of a five-man board of directors were concededly hostile to the shareholders' claim against the third-party wrongdoer. ${ }^{43}$ The other three directors had stated in depositions that they were not controlled by the outsider, would investigate the plaintiffs' com-

shareholders have complied with the demand on directors requirement, they still must establish standing to sue. See text and notes at notes 149-216 infra.

${ }^{35}$ Nussbacher v. Continental Ill. Nat'l Bank \& Trust Co., 518 F.2d 873, 877 (7th Cir. 1975), cert. denied, 424 U.S. 928 (1976).

36 Tasner v. Billera, 379 F. Supp. 815, 826 (N.D. Ill. 1974).

37 Lerman v. ITB Management Corp. 58 F.R.D. 153, 157-58 (D. Mass. 1973); Weiss v. Sunasco Inc., 316 F. Supp. 1197, 1206 (E.D. Pa. 1970).

${ }^{3 x}$ E.g., Delaware \& H. Co. v. Albany \& S.R.R., 213 U.S. 435 (1909); Doctor v. Harrington, 196 U.S. 579 (1905); In re Kauffman Mut. Fund Actions, 479 F.2d 257 (1st Cir.), cert. denied, 414 U.S. 857 (1973); Cathedral Estates, Inc. v. Taft Realty Corp., 228 F.2d 85 (2d Cir. 1955); Abbe v. Goss, 411 F. Supp. 923 (S.D.N.Y. 1975); Jones v. Equitable Life Assurance Soc'y, 409 F. Supp. 370 (S.D.N.Y. 1975).

39 E.g., Doctor v. Harrington, 196 U.S. 579 (1905).

10 Id.

"See Delaware \& H. Co. v. Albany \& S.R.R., 213 U.S. 435, 448-49 (1909).

12286 F. Supp. 809 (D. Colo. 1968), aff'd, 435 F.2d 1223 (10th Cir. 1970).

13 Id. at 814 . 
plaint, and would take appropriate action. ${ }^{44}$ In certain instances, the three had voted contrary to the wishes of the third-party wrongdoer. ${ }^{45}$ Nevertheless, the court held that demand was not required because the three directors were elected by the outsider, had taken little interest in the corporation's affairs, and were therefore not "the kind of active and aggressive majority that would be likely to undertake the difficult and demanding task of prosecuting a lawsuit." ${ }^{16}$ The Tenth Circuit affirmed, noting that "[c]ourts have generally been lenient in excusing demand." 47

The facts of de Haas present a close case. The court may have been correct that the directors probably would not have diligently investigated and acted upon the shareholders' complaint. But given the contrary claims of the directors and their previous history of independent voting, demand should have been required. If the directors rejected the demand, the complaining shareholders could then institute the suit-after the corporation had been given a chance to vindicate its own rights..$^{48}$

The majority of the cases have taken the view that unsupported allegations that the directors are controlled by the alleged wrongdoers are insufficient to excuse demand ${ }^{49}$ In cases where specific uncontroverted facts are produced to support the allegation of control, courts have properly held that making demand on directors would be futile. ${ }^{50}$ In these instances the interests of the directors are clearly antagonistic to those of the shareholders, rendering the demand requirement a useless formality. ${ }^{51}$

2. Conflict of Interest. A second ground often advanced by

\footnotetext{
s Id.

is Id.

16 Id.

17435 F.2d 1223, 1228 (10th Cir. 1970).

13 The minority shareholder would then have an opportunity to prove that the directors were controlled in order to establish standing to sue. See text and notes at notes 164-166 infra.

19 E.g., In re Kauffman Mut. Fund Actions, 479 F.2d 257 (1st Cir.), cert. denied, 414 U.S. 857 (1973); Jones v. Equitable Life Assurance Soc'y, 409 F. Supp. 370 (S.D.N.Y. 1975); Abrams v. Mayflower Investors, Inc., 62 F.R.D. 361 (N.D. Ill. 1974); Baffino v. Bradford, 57 F.R.D. 79 (D. Minn. 1972).

so In most of these cases the wrongdoer owned a substantial percentage of the stock in the complaining shareholders' corporation. See, e.g., Cathedral Estates, Inc. v. Taft Realty Corp., 228 F.2d 85 (2d Cir. 1955); Abbe v. Goss, 411 F. Supp. 923 (S.D.N.Y. 1975); Dopp v. American Electronic Labs., Inc., 55 F.R.D. 151 (S.D.N.Y. 1972). A particularly appropriate case for excusing demand because of control is Maxwell v. Enterprise Wall Paper Mfg. Co., 47 F. Supp. 999, 1001 (E.D. Pa.), rev'd on other grounds, 131 F.2d 400 (3d Cir. 1942), where it was alleged that the individual defendant held the majority of the stock, that such stock ownership gave him complete control of the election of directors and the management of the business, and that he had not permitted corporate meetings to be held for the last five years.

st See Delaware \& H. Co. v. Albany \& S.R.R., 213 U.S. 435, 451 (1909).
} 
complaining shareholders to justify their failure to make demand on the directors is that the directors would not prosecute the claim vigorously because of a conflict of interest. ${ }^{52}$ In cases of an actual conflict of interest-as where the same people are the directors of the plaintiffs' corporation and of a second defendant corporation, ${ }^{53}$ or where the directors have a substantial financial interest in another defendant corporation ${ }^{54}$-demand should not be required. But courts should carefully scrutinize the facts to ensure that the alleged conflict of interest is genuine.

The case of Landy $v$. Federal Deposit Insurance Corp. ${ }^{55}$ illustrates the proper judicial approach to an allegation of conflict of interest. In Landy, shareholders of an insolvent bank brought actions against numerous defendants to recover losses sustained in various security speculations. The shareholders alleged that no demand was necessary on the FDIC (which was acting as receiver for the bank) because of various conflicts of interest faced by the FDIC. ${ }^{56}$ The court examined the arguments for each of the supposed conflicts, ${ }^{57}$ found none of them persuasive, ${ }^{58}$ and therefore held that demand was required.

Thus, allegations of conflict of interest, like allegations of control, should not automatically obviate the demand requirement. Only in cases where the interests of the directors are clearly adverse to the interests of the shareholders should demand not be required.

3. Director Participation in the Transaction Attacked. Courts have had the greatest difficulty in determining whether demand should be excused when the shareholders allege that demand would be futile because the directors participated or acquiesced in the challenged transaction. ${ }^{59}$ Shareholders have argued that it would be

32 E.g., Delaware \& H. Co. v. Albany \& S.R.R., 213 U.S. 435 (1909); Landy v. FDIC, 486 F.2d 139 (3d Cir. 1973), cert. denied, 416 U.S. 960 (1974); Cathedral Estates, Inc. v. Taft Realty Corp., 228 F.2d 85 (2d Cir. 1955).

ss Delaware \& H. Co. v. Albany \& S.R.R., 213 U.S. 435, 443 (1909); Phillips v. Bradford, 62 F.R.D. 681,688 (S.D.N.Y. 1974).

st E.g., Cathedral Estates, Inc. v. Taft Realty Corp., 228 F.2d 85 (2d Cir. 1955).

s5 486 F.2d 139 (3d Cir. 1973), cert. denied, 416 U.S. 960 (1974).

st Id. at 147 .

${ }^{57}$ In Landy, the alleged conflicts were based on various statutory duties of FDIC. Since the alleged conflict of interest was based solely on law, no trial of disputed facts was required.

sk Id. at 149-50.

5) E.g., Nussbacher v. Continental Ill. Nat'l Bank \& Trust Co., 518 F.2d 873 (7th Cir. 1975), cert. denied, 424 U.S. 928 (1976). In re Kauffman Mut. Fund Actions, 479 F.2d 257 (1st Cir.), cert. denied, 414 U.S. 857 (1973); Jones v. Equitable Life Assurance Soc'y, 409 F. Supp. 370 (S.D.N.Y. 1975); Brooks v. American Export Indus., Inc., 68 F.R.D. 506 (S.D.N.Y. 1975); Kusner v. First Pa. Corp., $395^{\circ}$ F. Supp. 276 (E.D. Pa. 1975); Cohen v. Industrial Fin. Corp., 44 F. Supp. 491 (S.D.N.Y. 1942). 
unreasonable to expect the directors to enforce the rights of the corporation when the directors would in effect be suing themselves. ${ }^{60}$

When a majority of the directors have engaged in fraud or selfdealing, such as appropriating a corporate opportunity, courts have generally not required demand. ${ }^{61}$ But when a majority of the directors are accused of approving or passively acquiescing in an allegedly injurious transaction, courts are split on whether demand should be required.62 The majority view is expressed in the leading

${ }^{60}$ E.g., Nussbacher v. Continental IIl. Nat'l Bank \& Trust Co., 518 F.2d 873, 875 (7th Cir. 1975), cert. denied, 424 U.S. 928 (1976); Meyers v. Keeler, 414 F. Supp. 935, 938 (W.D. Okla. 1976); Brooks v. American Export Indus., Inc., 68 F.R.D. 506, 509-10 (S.D.N.Y. 1975); Heit v. Bixby, 276 F. Supp. 217, 223 (E.D. Mo. 1967). Some courts have accepted this reasoning. In Cohen v. Industrial Fin. Corp., 44 F. Supp. 491, 495 (S.D.N.Y. 1942), the court stated:

It is alleged that these directors 'have had knowledge of all the facts complained of herein and have acquiesced and participated therein.' ... The requirement of a demand should be dispensed with, where it is clear that a demand would be a useless gesture. Indeed, in cases such as this, where other representative actions by stockholders have been 'settled,' against the real interests of the injured corporation, it would be the height of folly to entrust the conduct of the litigation, either directly or indirectly, to the very people who are responsible for the wrongs, according to the complaint.

In the event that the directors accept the shareholders' demand to institute a suit, but eventually settle contrary to the interests of the corporation, the shareholders are not without a remedy; they can sue the directors for breach of fiduciary duty. See also In re Kauffman Mut. Fund Actions, 479 F.2d 257, 267 (1st Cir.) (Coffin, C.J., concurring), cert. denied, 414 U.S. 857 (1973).

st E.g., Steinberg v. Hardy, 90 F. Supp. 167 (D. Conn. 1950); Craftsman Fin. \& Mortgage Co. v. Brown, 64 F. Supp. 168 (S.D.N.Y. 1945); Abraham v. Parkins, 36 F. Supp. 238 (W.D. Pa. 1940); Parish v. Maryland \& Va. Milk Producers Ass'n, 250 Md. 24, 242 A.2d 512 (1968), cert. denied, 404 U.S. 940 (1971); Caldwell v. Eubanks, 326 Mo. 185, 30 S.W.2d 976 (1930). But cf. Watson v. United States Sugar Refinery, 68 F. 769 (7th Cir. 1895) (allegation that majority of the directors are implicated in fraud does not eliminate necessity for demand). In some cases, courts have excused demand even though only a minority of directors have engaged in self-dealing. See, e.g., Meltzer v. Atlantic Research Corp., 330 F.2d 946 (4th Cir.), cert. denied, 379 U.S. 841 (1964) (demand not required where two of five directors accused of self-dealing). But cf. Bartlett v. New York, N.H. \& H.R.R., 221 Mass. 530, 109 N.E. 452 (1915) (demand on directors required when only ten out of twenty-three accused of wrongdoing). The recent case of Nussbacher v. Continental Ill. Nat'l Bank \& Trust Co., 518 F.2d 873 (7th Cir. 1975), cert. denied, 424 U.S. 928 (1976), suggests a new approach to the problem of excusing a failure to make demand when a majority of the directors are accused of participating in an illegal or injurious transaction. The court stated that it attached "no significance" to whether the directors could be held civilly or criminally liable; the resolution of this question was relevant to the merits, not to whether demand on directors was necessary. Id. at $878 \mathrm{n} .9$.

If the directors who once constituted a majority of the board are replaced with new directors, demand must be made on the new directors. Brody v. Chemical Bank, 517 F.2d 932, 934 (2d Cir. 1975); Brody v. Chemical Bank, 482 F.2d 1111, 1114 (2d Cir.), cert. denied, 414 U.S. 1104 (1973); Nelson v. Pacific Southwest Airlines, 399 F. Supp. 1025, 1030 (S.D. Cal. 1975); Independent Investor Protective League v. Saunders, 64 F.R.D. 564, 571 (E.D. Pa. 1974).

"2 Most cases have refused to excuse the failure to make demand in this situation. E.g., 
case of In re Kauffman Mutual Fund Actions, ${ }^{63}$ holding that the mere approval of an allegedly injurious corporate transaction, absent self-interest or bias, is insufficient to excuse the failure to make demand on directors. ${ }^{64}$ The approach in Kauffman is not free from difficulty. Directors undertake affirmative duties of due care and

In re Kauffman Mut. Fund Actions, 479 F.2d 257 (1st Cir.), cert. denied, 414 U.S. 857 (1973); Jones v. Equitable Life Assurance Soc'y, 409 F. Supp. 370 (S.D.N.Y. 1975); Brooks v. American Export Indus., Inc., 68 F.R.D. 506 (S.D.N.Y. 1975); Kusner v. First Pa. Corp., 395 F. Supp. 276 (E.D. Pa. 1975). But see Papilsky v. Berndt, 59 F.R.D. 95 (S.D.N.Y. 1973), appeal dismissed, 503 F.2d 554 (2d Cir.), cert. denied, 419 U.S. 1048 (1974); Barr v. Wackman, 36 N.Y.2d 371, 329 N.E.2d 180, 368 N.Y.S.2d 497 (1975); Galfand v. Chestnutt, 402 F. Supp. 1318 (S.D.N.Y. 1975).

a 479 F.2d 257 (1st Cir.), cert. denied, 414 U.S. 857 (1973).

4 Id. at 265-66. The court in Kauffman also had to decide whether different standards for demand on directors should apply in cases involving mutual funds. Most mutual funds are operated not by their own employees but by separately owned external organizations, usually called investment advisors. The investment advisor receives management fees for these services. Because of this unique structure, the fund and its investment advisor stand in a relationship different from that usually existing between buyers and sellers in corporate contexts. The First Circuit, however, refused to excuse demand on an independent majority of directors when a shareholder alleged a corporate injury stemming from the advisor-fund relationship. Id. at 266.

The continuing vitality of this aspect of Kauffman has been called into question by the recent case of Boyko v. Reserve Fund, Inc., 68 F.R.D. 692 (S.D.N.Y. 1975). In Boyko, the plaintiff brought $a$ derivative action based on the allegedly excessive management fee schedule existing between the fund and its investment advisor. No demand was made on the directors because they had approved of the transaction attacked. The court acknowledged that plaintiff's allegations were virtually indistinguishable from those in Kauffman and that under prevailing authority the demand requirement would therefore need to be met. Id. at 694-95. The court held, however, that this case was distinguishable from Kauffman because that case was litigated prior to the effective date of $\S 36(\mathrm{~b})$ of the Investment Company Act, 15 U.S.C. $\$ 80 \mathrm{a}-35$ (b) (1970), which provides in relevant part that

the investment advisor of a registered investment company shall be deemed to have a fiduciary duty with respect to the receipt of compensation for services . . . paid by such registered investment company .... .

The novel question before the court, therefore, was the interaction of this newly created statutory fiduciary duty of the investment advisor with the demand on directors requirement. The court held that in a derivative action based on $\S 36(\mathrm{~b})$, the demand required by rule 23.1 need not be made whenever there is at least one interested person, as that term is defined in $\S 2(\mathrm{a})(19), 15$ U.S.C. $\S 80 \mathrm{a}-2(\mathrm{a})(19)$ (1970), on the board of directors of the mutual fund. Id. at 697 . The holding of the court was premised on its observation that "the derivative action designed expressly to enforce the specific fiduciary duty created by Rule 36(b) should not be rendered meaningless by an application of the more general provisions of Rule 23.1 and the case law generally applicable to derivative actions." Id. at 696.

The reasoning of the court is suspect. Forcing a shareholder to exhaust intracorporate remedies by mailing a copy of the complaint to the directors of the fund before bringing a derivative action would hardly seem to frustrate the policies embodied in $\S 36(\mathrm{~b})$. It is also significant that the legislative history of $\S 36$ (b) does not mention any modification of the traditional exhaustion requirement, suggesting that none was intended. The court in Boyko could have excused the failure to make demand on more conventional grounds, since the fund's directors had admitted their opposition to the suit. Id.; see text and notes at notes 79-86 infra. 
diligence in addition to their obligation to avoid breaches of their fiduciary duty of loyalty. ${ }^{65} \mathrm{~A}$ director does not exempt himself from liability by passively rubber-stamping decisions that cause harm to the corporation. ${ }^{6}{ }^{6}$ However, there are compelling reasons for requiring demand when the only justification for a failure to make demand is that the directors acquiesced in the transaction under attack.

First, it is unclear that acquiescence in an illegal or injurious transaction absent self-interest or bias should create an irrebuttable presumption that directors would not entertain a claim for relief, ${ }^{67}$ particularly when a third-party wrongdoer is involved. When the claim is that the transaction between the corporation and a third party violated positive law, such as the antitrust laws ${ }^{68}$ the directors would probably not be barred by the in pari delicto defense from suing the third party. ${ }^{69}$ Similarly, when the allegation is that the corporation was fraudulently induced to enter a contract harmful to the corporation, the directors could take appropriate measures to void the contract and recover any damages suffered..$^{70}$ Even when no third-party wrongdoer is involved, demand should arguably still be required to give the directors an opportunity to fulfill their fiduciary obligations and to correct any harm they may have caused. ${ }^{71}$ The

${ }^{85}$ See generally Dyson, The Director's Liability for Negligence, 40 IND. L.J. 341 (1965); Feuer, Liabilities of Directors and Officers, 5 N.Y.L.F. 127 (1959).

" See Barr v. Wackman, 36 N.Y.2d 371, 329 N.E.2d 180, 368 N.Y.S.2d 497 (1975).

"7 "The directors represent all the stockholders and are presumed to act honestly and according to their best judgment for the interests of all." Corbus v. Alaska Treadwell Gold Mining Co., 187 U.S. 455, 463 (1903). In In re Kauffman Mut. Fund Actions, 479 F.2d 257, 266-67 (1st Cir.), cert. denied, 414 U.S. 857 (1973), the court emphasized that participation in an injurious or illegal transaction or approval of it does not extinguish, but rather refocuses the fiduciary duty of the directors to act in the best interests of the corporation by rectifying their prior error in judgment.

${ }^{8}$ See In re Kauffman Mut. Fund Actions, 479 F.2d 257, 261 (1st Cir.), cert. denied, 414 U.S. 857 (1973).

" Perma Life Mufflers, Inc. v. International Parts Corp., 392 U.S. 134 (1968). Although the in pari delicto defense has traditionally been available in private securities actions, see generally Comment, Plaintiff's Conduct as a Bar to Recovery Under the Securities Acts: In Pari Delicto, 48 Texas L. Rev. 181 (1969), the modern trend is to reject the defense in securities actions. See Woolf v. S.D. Cohn \& Co., 515 F.2d 591 (5th Cir. 1975) (Wisdom, J.), vacated on other grounds, 96 S.Ct. 3161 (1976); Pearlstein v. Scudder \& German, 429 F.2d 1136 (2d Cir. 1970). See generally Comment, The Demise of In Pari Delicto in Private Actions Pursuant to Regulatory Schemes, 60 Calif. L. Rev. 572 (1972).

70 Contracts induced by fraud are voidable. See 1 Corbin on Contracts $\S 6$, at 12-13 (1963).

"In Meltzer v. Atlantic Research Corp., 330 F.2d 946 (4th Cir.), cert. denied, 379 U.S. 841 (1964), demand on directors was not required where two of the five directors diverted corporate assets while the others failed to protect the corporate interest. Rather than denying the acts alleged in the complaint, the defendant directors claimed that demand would not be futile because they had taken various rehabilitative measures, such as changing the mem- 
directors will have every incentive to take such action to avoid a subsequent shareholder suit against them for their alleged previous wrongdoing.

Second, eliminating the necessity for demand on the basis of allegations that the directors participated in an injurious transaction would seriously undermine the demand on directors requirement. Complaining shareholders almost invariably allege some illegal transaction or conduct harmful to the corporation. ${ }^{72}$ If such allegations were sufficient to excuse a failure to make demand, then such failure would be excused in nearly every case because the directors have a duty to participate in all major transactions of the corporation. ${ }^{73}$

Finally, excusing a failure to make demand because the directors participated in an illegal or injurious transaction would greatly encourage sham pleading. Minority shareholders should not be allowed to name directors as defendants for participating in the challenged transaction and then bootstrap the argument by asserting that since the directors are being sued, they cannot be relied upon to prosecute the action. ${ }^{74}$ The resolution of the question of director liability for participation in a transaction harmful to the corporation requires an extended inquiry into the merits of the shareholders' complaint, an inquiry inappropriate to the threshold issue of exhaustion of intracorporate remedies. ${ }^{75}$ Unless the shareholders spe-

bership of the board of directors, employing a law firm to act as counsel, procuring a reputable accounting firm, circulating financial statements, and obtaining guarantees for outstanding loans. Although the court found these rehabilitative measures inadequate to excuse the failure to make demand, the case illustrates that demand may have a salutary effect even if the directors are guilty of wrongdoing.

${ }^{72}$ In re Kauffman Mut. Fund Actions, 479 F.2d 257, 265 (1st Cir.), cert. denied, 414 U.S. 857 (1973).

${ }^{73}$ But see Graham v. Allis Chalmers Mfg. Co., 41 Del. Ch. 78, 188 A.2d 125 (1963) (holding that directors are entitled to rely on the honesty and integrity of their subordinates).

"One court has said of this practice:

This complaint has a bold and expansive thrust. It attempts to solve the problem of the specificity of demand under Rule 23.1 . . . by a simple device. It simply sues everybody ... . The plaintiff then "bootstraps" the argument, by asserting with an air of injured innocence, that since she is suing the . . . directors as well, how can she be expected to go to them for relief? . . . It is not for the plaintiff herself to build a wall around . . . [a] director . . . and then tell him he cannot jump over it.

Phillips v. Bradford, 62 F.R.D. 681, 688 (S.D.N.Y. 1974).

${ }^{75}$ Nussbacher v. Continental Ill. Nat'l Bank \& Trust Co., 518 F.2d 873 (7th Cir. 1975), cert. denied, 424 U.S. 928 (1976). In Papilsky v. Berndt, 503 F.2d 554, 556 (2d Cir.), cert. denied, 419 U.S. 1048 (1974), the Second Circuit rejected a claim that a limited inquiry into the merits was appropriate in determining whether demand on directors was necessary. But cf. Meyers v. Keeler, 414 F. Supp. 935, 939 (W.D. Okla. 1976) (the court conducted an evidentiary hearing to determine whether demand on directors was necessary). 
cifically allege fraud ${ }^{76}$ in the complaint or conclusively demonstrate by affidavits ${ }^{77}$ that the directors are interested in the transaction attacked, demand should be required. If demand is made and rejected, the complaining shareholders will then have a full opportunity to prove their claims that the directors are liable for participation in an injurious transaction. ${ }^{78}$

4. Director Opposition to Suit. Some cases have held that demand is not required when the directors have made it clear that they are opposed to bringing the suit urged by the complaining shareholders. ${ }^{79}$ In Nussbacher $v$. Continental Illinois National Bank \& Trust Co. ${ }^{80}$ for example, the plaintiff brought a derivative action -against the directors of the corporation and Continental Bank for injuries resulting from an allegedly illegal credit plan. The directors had previously refused to institute a suit in an almost identical action in another jurisdiction. ${ }^{81}$ In addition, the chairman of the board of directors had stated in an affidavit that he was opposed to the commencement of a lawsuit against the bank, believing it to be inconsistent with the best interests of the corporation..$^{82}$

Citing the obvious opposition of the directors, the plaintiff claimed that no demand on directors was necessary. ${ }^{83}$ The defendants argued that demand should be required since there was no showing of any disability making the directors unable to act impartially in the best interests of the corporation. ${ }^{84}$ The court felt that the defendants' position would require it to evaluate the wisdom of the directors' decision not to sue. The Seventh Circuit therefore rejected the defendants' argument, stating that the business judgment of the directors was relevant to the merits of the transactions complained of and not to whether demand was required. ${ }^{85}$ Finding "the message . . . loud and clear that under no circumstances would the board of directors have approved the corporation bringing

is Fraud must be specifically pleaded. FED. R. Crv. P. 9(b).

7 On the use of affidavits, see note 90 infra.

7x See text and notes at notes $168-75$ infra.

7 Nussbacher v. Continental Ill. Nat'l Bank \& Trust Co., 518 F.2d 873 (7th Cir. 1975), cert. denied, 424 U.S. 928 (1976); In re Pittsburgh \& L.E.R.R. Sec. \& Antitrust Litigation, 392 F. Supp. 492 (E.D. Pa. 1975). But see In re Kauffman Mut. Fund Actions, 479 F.2d 257, 263 (1st Cir.), cert. denied, 414 U.S. 857 (1973) (a shareholder must show not only that the directors are opposed to bringing the suit, but that they are "incapable of doing their duty").

xo 518 F.2d 873 (7th Cir. 1975), cert. denied, 424 U.S. 928 (1976).

"I Id. at 878.

${ }^{2}$ Id.

* Id. at 875.

\&s Id. at 877 .

*s Id. at 878. 
the action," quired.

The holding in Nussbacher is consistent with the purpose of the demand on directors requirement. ${ }^{87}$ Since the directors had unequivocally voiced their opposition to bringing an action against the bank, no purpose would be served by exhausting intracorporate remedies. That the directors may have made a correct assessment of the merits of the corporate claim in declining to bring suit is relevant to the plaintiff's standing to sue, ${ }^{88}$ not to whether intracorporate remedies need to be exhausted.

The demand on directors requirement should be strictly interpreted by the courts. Only in cases where the antagonism between the plaintiff shareholders and the directors is unmistakable-such as where the directors are controlled by the alleged wrongdoer, are handicapped by a genuine conflict of interest, or are resolutely opposed to bringing suit-should the failure to make demand on directors be excused. Rule 23.1's standard of "particularity" should not be satisfied by general unsupported allegations. Such a low standard would encourage boilerplate pleading to evade the demand requirement in all derivative suits. ${ }^{89}$ In cases where the facts concerning control or conflict of interest are controverted, affidavits should be considered ${ }^{90}$ Participation by the directors in the chal-

Id. at 879.

7 See text and notes at notes 22-24 supra.

* See text and notes at notes 151-58 infra.

"s Lerman v. ITB Management Corp., 58 F.R.D. 153, 159 (D. Mass. 1973).

" Courts are split on whether affidavits are appropriate for determining whether demand on directors is required. Compare Pioche Mines Consol., Inc. v. Dolman, 333 F.2d 257, 265 (9th Cir. 1964), cert. denied, 380 U.S. 956 (1965); Abrams v. Mayflower Investors, Inc., 62 F.R.D. 361, 368 (N.D. Ill. 1974); Lerman v. ITB Management Corp., 58 F.R.D. 153, 156 (D. Mass. 1973); and deHaas v. Empire Petroleum Co., 286 F. Supp. 809, 813-14 (1968), aff'd, 435 F.2d 1223 (10th Cir. 1970) (all approving use of affidavits), with Fields v. Fidelity Gen. Ins. Co., 454 F.2d 682, 684-85 (7th Cir. 1971); Brooks v. American Export Indus., Inc., 68 F.R.D. 506, 509 (S.D.N.Y. 1975); Papilsky v. Berndt, 59 F.R.D. 95, 98 (S.D.N.Y. 1973), appeal dismissed, 503 F.2d 554 (2d Cir.), cert. denied, 419 U.S. 1048 (1974) (all rejecting use of affidavits). Affidavits can be very helpful in analyzing the allegations of a complaint. In Abrams v. Mayflower Investors, Inc., 62 F.R.D. 361 (N.D. Ill. 1974), for instance, plaintiff claimed that demand on directors would be futile because the alleged wrongdoer controlled the board of directors. Id. at 367. Examination of uncontroverted affidavits, however, revealed that a majority of the directors were completely independent. Id. at 368. The court properly dismissed the action for failure to make demand on the directors.

It is conceivable that in some cases the use of affidavits will not be adequate to resolve controverted issues of fact. In this event, demand on directors should be required. A trialtype procedure is never appropriate in determining whether intracorporate remedies should be exhausted. See text at note 75 supra; cf. Smith v. Sperling, 354 U.S. 91 (1956) (pretrial hearing inappropriate to determine jurisdictional alignment). If the directors refuse to sue after demand has been made, the shareholder will have a full opportunity to prove his allegations at trial. See text and notes at notes 164-90 infra. 
lenged transaction absent self-interest or bias should not excuse the shareholders from demanding that the directors take action. Finally, the wisdom of the business judgment of the directors should not be relevant in determining whether exhaustion is required.

\section{The Demand on Shareholders Requirement}

Rule 23.1 of the Federal Rules of Civil Procedure requires a demand on shareholders "if necessary." Many states have also adopted a demand on shareholders requirement, ${ }^{92}$ although a few jurisdictions require demand only on directors. ${ }^{93}$ Like the requirement of demand on directors, the requirement of demand on shareholders rests on the premise that intracorporate remedies must be exhausted before complaining shareholders can maintain a derivative action. ${ }^{94}$ Significant differences exist, however, between the two types of demand. One of the primary advantages of the demand on directors requirement is that it gives the directors an opportunity to fulfill their normal role in managing the corporation. ${ }^{95}$ The demand on shareholders requirement does not have this advantage because shareholders normally do not play an active role in running the corporation's affairs. ${ }^{96}$ Furthermore, unlike the demand on directors requirement, the demand on shareholders requirement may impose significant expense and delay on the complaining shareholders and is therefore a potentially powerful deterrent to the

"For the text of rule 23.1, see note 8 supra. The words "if necessary" apparently were adopted from Hawes v. Oakland, 104 U.S. 450, 461 (1882). Professor Moore has argued that the phrase in rule 23.1 was meant to incorporate state law on whether the shareholders can ratify fraud. 3B Moore's Federal Practice qf 23.1.19, at 23.1-257 (2d ed. 1975). It is highly unlikely, however, that the words "if necessary" were intended to incorporate state law since the original rule was promulgated before Erie R.R. v. Tompkins, 304 U.S. 64 (1938). For a critique of the Moore view, see Note, The Nonratification Rule and the Demand Requirement: The Case for Limited Judicial Review, 63 CoLum. L. Rev. 1086, 1090 n.36 (1963): Nevertheless, many courts in diversity actions have held that state law determines the extent to which demand on shareholders is required, while federal law determines the requisite particularity of pleading. See, e.g., Steinberg v. Hardy, 90 F. Supp. 167 (D. Conn. 1950). For a discussion of whether state or federal law governs the necessity of making demand on shareholders in federal question cases, see note 131 infra.

12 E.g., Ariz. R. Civ. P. 23.1; Minn. R. Civ. P. 23.06.

${ }^{93}$ E.g., Cal. Corp. Code $\S 834$ (West 1955); N.Y. Bus. Corp. LaW $\S 626$ (c) (McKinney 1963).

"Hawes v. Oakland, 104 U.S. 450 (1882).

15 See text at note 25 supra.

"A demand on shareholders does, however, allow the shareholders to express their views on the wisdom of bringing suit, elect a new board of directors to pursue the alleged cause of action, join the suit as derivative plaintiffs, or attempt to induce the directors to bring the action. There is no case law defining what the subject matter of a demand on shareholders must be. See Demand on Directors, supra note 28, at 749. 
maintenance of derivative actions. ${ }^{97}$

In response to these unique characteristics of the demand on shareholders requirement, courts have adopted widely differing theories on when demand on shareholders is necessary and when it can be excused.

\section{A. Differing Theories of Requiring Demand on Shareholders}

Two different theories are used to determine when demand on shareholders is necessary: the ratification theory and the business judgment theory.$^{98}$ Under the ratification theory, followed in a majority of jurisdictions, demand is required only when the alleged wrong can be ratified by a majority vote of the shareholders. ${ }^{99}$ The rationale is that a demand presumes that shareholders are able to take remedial measures: where shareholders have no power to ratify actions, no purpose is served by requiring demand. ${ }^{100}$ As a general rule, conduct that is fraudulent, illegal, or ultra vires is nonratifiable, and therefore demand on shareholders is unnecessary when such conduct is alleged. ${ }^{101}$ Because complaining shareholders almost invariably allege that the action complained of falls within one of

" Pomerantz v. Clark, 101 F. Supp. 341, 344 (D. Mass. 1951).

"See, e.g., Leavell, The Shareholders as Judges of Alleged Wrongs by Directors, 35 TuL. L. Rev. 331 (1961); Note, The Nonratification Rule and the Demand Requirement: The Case for Limited Judicial Review, 63 CoLum. L. REv. 1086 (1963); Demand on Directors, supra note 28.

" E.g., Brody v. Chemical Bank, 482 F.2d 1111 (2d Cir.), cert. denied, 414 U.S. 1104 (1973); Mayer v. Adams, 37 Del. Ch. 298, 141 A.2d 458 (Sup. Ct. 1958); Saigh v. Busch, 396 S.W.2d 9 (Mo. Ct. App. 1965), cert. denied, 384 U.S. 942 (1966); Continental Sec. Co. v. Belmont, 206 N.Y. 7, 99 N.E. 138 (1912).

The question of excusing demand because the wrong complained of is nonratifiable is distinguishable from the question whether demand is required when shareholders have earlier expressed their approval of the challenged transaction. Several courts have required demand in the latter situation on the ground that the shareholders might be convinced by the demand despite their earlier approval of the challenged transaction. E.g., Dickinson v. Consolidated Traction Co., 114 F. 232, 246-47 (C.C.D.N.J. 1902), aff'd on other grounds, 119 F. 871 (3d Cir.), cert. denied, 191 U.S. 567 (1903); cf. Claman v. Robertson, 164 Ohio St. 61, 72-73, 128 N.E.2d 429, 436 (1955) (prior ratification by shareholders could be negated by the acceptance of a subsequent demand on shareholders). Other courts, however, have considered demand futile where stockholders had approved of the transaction under attack. See, e.g., Security Trust Co. v. Dabney, 372 S.W.2d 401 (Ky. Ct. App. 1963); Parish v. Maryland \& Va. Milk Producers Ass'n, 250 Md. 24, 242 A.2d 512 (1968); Hyams v. Old Dominion Co., 113 Me. 294, 93 A. 747 (1915).

${ }_{100}$ Mayer v. Adams, 37 Del. Ch. 298, 141 A.2d 458 (Sup. Ct. 1958).

in 13 W. Fletcher, Cyclopedia of the Law of Private Corporations $\S 5795$, at 96 (rev. perm. ed. 1970). But cf. Mountain States Packing Co. v. Curtis, 86 Colo. 355, 281 Pac. 737 (1929) (shareholders can ratify directors' fraud); Claman v. Robertson, 164 Ohio St. 61, 128 N.E.2d 429 (1955) (same). 
these three categories, the ratification theory has the effect of eviscerating the demand on shareholders requirement. ${ }^{102}$

Under the business judgment theory, demand on shareholders is required in all derivative actions where there is a disinterested majority of shareholders. ${ }^{103}$ Demand is required even when the wrong is technically nonratifiable on the ground that the shareholders should be permitted to join in the suit, ${ }^{104}$ elect new directors to pursue the cause of action, ${ }^{105}$ or persuade the directors to bring the action. ${ }^{106}$ Most important, demand allows the majority of shareholders to exercise their business judgment whether the suit should be brought. ${ }^{107}$ This theory assumes that the shareholders are entitled to exercise their judgment whether the best interests of the corporation will be served by bringing the action, even though the power to run the corporation's affairs is normally vested in the directors. ${ }^{108}$

Neither theory provides an adequate conceptual framework for determining when demand on shareholders is necessary. The ratification theory allows complaining shareholders to circumvent the demand requirement by simply pleading a cause of action that is nonratifiable. ${ }^{109}$ The business judgment theory, on the other hand, is excessively rigid, often requiring demand when the realities of the modern publicly held corporation make the mechanics of demand unfeasible. ${ }^{110}$

\section{B. Excuses for Failure to Make Demand on Shareholders}

Three reasons are typically given as excuses for failure to make demand on shareholders: the lack of a disinterested majority of shareholders, the nonratifiability of the wrong complained of, and

102 Note, The Nonratification Rule and the Demand Requirement: The Case for Limited Judicial Review, 63 Colum. L. Rev. 1086, 1086-87 (1963).

${ }^{103}$ See, e.g., Halprin v. Babbitt, 303 F.2d 138 (1st Cir. 1962); Pomerantz v. Clark, 101 F. Supp. 341 (D. Mass. 1951); American Life Ins. Co. v. Powell, 262 Ala. 560, 80 So.2d 487 (1954); cf. S. Solomont \& Sons Trust v. New England Theatres Operating Corp., 326 Mass. 99, 93 N.E.2d 241 (1950) (holding that a negative shareholder vote bars a derivative action).

wo E.g., Halprin v. Babbitt, 303 F.2d 138 (1st Cir. 1962); Bell v. Arnold, 175 Colo. 277, 487 P.2d 545 (1971).

${ }_{105}$ E.g., Abraham v. Parkins, 36 F. Supp. 238 (W.D. Pa. 1940); Bell v. Arnold, 175 Colo. 277, 487 P.2d 545 (1971).

${ }^{106}$ See Demand on Directors, supra note 21 at 750-51.

${ }_{107}$ E.g., Halprin v. Babbitt, 303 F.2d 138 (1st Cir. 1962); American Life Ins. Co. v. Powell, 262 Ala. 560, 80 So.2d 487 (1954); Claman v. Robertson, 164 Ohio St. 61,128 N.E.2d 429 (1955).

tox The leading case expressing this view is S. Solomont \& Sons Trust v. New England Theatres Operating Corp., 326 Mass. 99, 93 N.E.2d 241 (1950).

${ }^{109}$ Gottesman v. General Motors Corp., 268 F.2d 194 (2d Cir. 1959).

${ }^{110}$ See Pomerantz v. Clark, 101 F. Supp. 341, 344 (D. Mass. 1951). 
undue expense or delay. Examining these reasons reveals the advantages and disadvantages entailed by each.

1. The Lack of a Disinterested Majority of Shareholders. Under both the ratification and the business judgment theories, the lack of a disinterested majority of shareholders dispenses with the necessity for making a demand on shareholders. When a majority of the shareholders are the alleged wrongdoers and the demand would therefore be a request that these shareholders sue themselves, a failure to make demand has been excused. ${ }^{111}$ Similarly, demand has not been required when the alleged wrongdoers have working control of the corporation by virtue of their stock ownership. ${ }^{112}$ The difficult question is the amount of ownership necessary for working control. Courts have generally been lenient in excusing demand on shareholders where the wrongdoers owned a significant, although less than majority, interest of the outstanding stock. ${ }^{113}$ This approach is consistent with the structure of large publicly held corporations with many small shareholders who are likely to be widely scattered, uninformed, and unorganized..$^{114}$

2. The Nonratifiability of the Wrong. Under the ratification theory, demand is not required when the alleged wrong is nonratifiable. Thus, in the leading case of Continental Securities Co. $v$. Belmont, ${ }^{115}$ the plaintiffs brought a derivative action against the directors of Interborough Rapid Transit System for allegedly misappropriating $\$ 4,500,000$ by fraudulently and illegally issuing 15,000 shares of capital stock without receiving consideration. ${ }^{116}$ Finding the transaction attacked nonratifiable, the court held that the failure to make demand on shareholders was excused. ${ }^{117}$ The court spe-

II' E.g., Cohen v. Industrial Fin. Corp., 44 F. Supp. 491 (S.D.N.Y. 1942); Decatur Mineral Land Co. v. Palm, 113 Ala. 531, 21 So. 315 (1896); Fornaseri v. Cosmosart Realty \& Bldg. Corp., 96 Cal. App. 549, 274 Pac. 597 (1929); North v. Union Sav. \& Loan Ass'n, 59 Ore. 483, 117 Pac. 822 (1911).

112 Delaware \& H. Co. v. Albany \& S.R.R., 213 U.S. 435 (1909); Gottesman v. General Motors Corp., 268 F.2d 194 (2d Cir. 1959); Hyams v. Calumet \& Hecla Mining Co., 221 F. 529 (6th Cir. 1915).

${ }^{113}$ Delaware \& H. Co. v. Albany \& S.R.R., 213 U.S. 435 (1909); Hyams v. Calumet \& Hecla Mining Co., 221 F. 529 (6th Cir. 1915). But see Carroll v. New York, N.H. \& H.R.R., 141 F. Supp. 456 (D. Mass. 1956).

"' Note, Shareholder Demand as a Condition Precedent to Derivative Suits-A Proposed Compromise, 30 U. CiN. L. REv. 196, 201 (1961).

is 206 N.Y. 7, 99 N.E. 138 (1912).

i' Id. at $11-12,99$ N.E. at $139-40$.

117 Id. at 19-20, 99 N.E. at 142-43. The court emphasized that its decision was not in conflict with the rule laid down in Hawes v. Oakland, 104 U.S. 450 (1882), that demand on shareholders was necessary unless it was "not reasonable to require it." Id. at 461 . Since the shareholders could not ratify the alleged wrong, it would be "unreasonable and unnecessary" 
cifically rejected the theory that shareholders have power to exercise business judgment whether a derivative suit should be brought. ${ }^{118 .}$ Arguments that the shareholders should be given an opportunity to take action, either by requiring the directors to bring suit ${ }^{119}$ or by voting out the directors at the next election, ${ }^{120}$ were also rejected.

Other courts, however, have found merit in the possibility that shareholders might take remedial actions other than ratification and have therefore required demand even when the alleged wrong was nonratifiable. ${ }^{121}$ Critical to these cases is the assumption that minority shareholders should not be able to institute a derivative action against the will of the majority, regardless of the nature of the wrong. ${ }^{122}$ In American Life Insurance Co. v. Powell, ${ }^{123}$ for example, the court stated that, even though the complaint alleged fraud on the part of the directors, a nonratifiable wrong, demand had to be made on the shareholders because they have "the final authority to determine whether or not it would be good business policy"124 to sue.

The major conceptual problem with this argument is that, as a general rule, shareholders exercise business judgment only by electing directors; thereafter, shareholders are excluded from participation in managing the corporation. ${ }^{125}$ It is normally the function of

to require demand. 206 N.Y. at 19,99 N.E. at 142 (1912). The court's reasoning is specious because Hawes dealt with demand on shareholders as a means of exhausting intracorporate remedies and preventing collusive suits, not with ratification.

"IX The court stated that the argument that the shareholders should be given an opportunity to exercise business judgment was "based upon an erroneous conception of the duties and powers of the body of stockholders . . ." 206 N.Y. at 16, 99 N.E. at 141 . Other cases have reached the same result. See, e.g., Mayer v. Adams, 37 Del. Ch. 298, 141 A.2d 458 (Sup. Ct. 1958).

11' 206 N.Y. at 17,99 N.E. at $141-42$.

120 Id.

121 See cases cited at note 103 supra.

122 E.g., S. Solomont \& Sons Trust v. New England Theatres Operating Corp., 326 Mass. 99, 93 N.E.2d 241 (1950). The court in Solomont emphasized that, even if the shareholders have no power to ratify, "[t]he question whether it is good judgment to sue is quite apart from the question of ratification." Id. at 111, 93 N.E.2d at 247. Other courts, however, have rejected the distinction between ratification and a decision not to sue. E.g., Rogers v. American Can Co., 305 F.2d 297, 317-18 (3d Cir. 1962); Mayer v. Adams, 37 Del. Ch. 298, 304, 141 A.2d 458, 461 (Sup. Ct. 1958). The two concepts are distinguishable in that ratification rectifies the wrong, whereas a decision not to sue bars a recovery. The effect in both cases, however, is the same-minority shareholders are precluded from maintaining a derivative action.

123262 Ala. 560,80 So.2d 487 (1954).

${ }^{124}$ Id. at 567,80 So.2d at 492.

${ }^{125}$ Shareholders do exercise some power on matters outside the ordinary business of the corporation. Modern statutes typically require shareholder approval of such extraordinary matters as sales of all or substantially all the corporate assets other than in the normal course 
the directors to decide whether or not to pursue a cause of action: the best interests of the corporation are not served by pursuing every claim. ${ }^{126}$ But, in the event that the directors either are unable to exercise or fail to exercise sound business judgment, ${ }^{127}$ the shareholders are the only corporate entity available to decide whether a claim for the benefit of the corporation should be pursued. The question then becomes whether minority shareholders should be allowed to maintain a derivative action without first going to the majority of the shareholders, who may believe that it would be unwise or even ruinous for the corporation to sue. In this situation the shareholders, the true equitable owners of the corporation, should be given an opportunity to express their views on whether the action should be brought. ${ }^{128}$ This is particularly true for close corporations characterized by a small number of shareholders who have expectations of participating in decision making and settling differences by majority vote. ${ }^{129}$

Even if shareholders have some residual power to exercise business judgment whether a suit should be brought, demand on shareholders should not always be required. Allowing shareholders the opportunity to exercise business judgment assumes that they can do so intelligently, based on adequate knowledge of the facts and legal theories underlying the alleged cause of action. The decision whether or not to sue is a complicated one for directors, even with their access to information and counsel. It is difficult to imagine how a shareholder in a large, publicly held corporation could make an informed judgment on the wisdom of pursuing a claim arising

of business, amendments of the articles of incorporation, mergers, consolidations, and nonjudicial dissolutions. See H. Henn, Handoook of the Law of Corporations 694-723 (2d ed. 1970). For a discussion of whether allowing shareholders to sue violates the "statutory norm," see Leavell, supra note 98, at 360-63.

126 The cause of action may have little merit, or the costs of pursuing the claim may be greater than any possible recovery.

${ }^{127}$ See text and notes at notes $164-90$ infra.

12x The corollary of requiring demand to enable shareholders to exercise their business judgment is that a negative vote by shareholders will bar a derivative suit. See text and notes at notes $200-16$ infra.

123 Eisenberg, The Legal Roles of Shareholders and Management in Modern Corporate Decisionmaking, 57 CALIF. L. REv. 1, 7-8 (1969). For cases requiring demand on shareholders where the number of shareholders is relatively small, see, e.g., Halprin v. Babbitt, 303 F.2d 138 (1st Cir. 1962) (92\% of stock owned by one shareholder); Johnson v. Espey, 341 F. Supp. 764 (S.D.N.Y. 1972) (less than ten shareholders). In American Life Ins. Co. v. Powell, 262 Ala. 560, 567, 80 So.2d 487, 492 (1954), the court stated that requiring demand on shareholders to give them an opportunity to exercise their business judgment was particularly appropriate in small corporations, where "democracy is usually a living fact rather than some fine theory seeking expression in the dormant verbiage of corporate charters or the high-toned eloquence of judicial discussion." 
from a complex corporate transaction, based on information compressed into proxy materials. ${ }^{130}$ If no fair and full consideration by the other shareholders is possible, demand should not be required..$^{131}$

130 See Leavell, supra note 98 , at $352-55$.

131 In Levitt v. Johnson, 334 F.2d 815 (1st Cir. 1964), cert. denied, 379 U.S. 961 (1965), for example, the court refused to require demand where the corporation had 48,000 stockholders whose identity was constantly changing scattered all over the country. The court was forced to distinguish an earlier case, Halprin v. Babbitt, 303 F.2d 138 (1st Cir. 1962), which had held that demand was required. 303 F.2d at 141. The court stated that Halprin was not controlling because in that case $92 \%$ of the company's stock was owned by one stockholder. The court emphasized that Halprin was a diversity case, whereas the instant action was brought under the Investment Company Act of 1940, 15 U.S.C. $\S \S 80 \mathrm{a}-1$ to -52 (1970). Therefore, Halprin did not "answer the question of what law presently governs." $334 \mathrm{~F} .2 \mathrm{~d}$ at 817. The question of whether federal or state law governed whether demand was necessary was crucial because, under the law of Massachusetts, demand would have been required regardless of cost. Pomerantz v. Clark, 101 F. Supp. 341, 344 (D. Mass. 1951). Because of the heavy financial burden involved, the derivative action probably could not have been maintained. The court held that the Massachusetts rule was inapplicable to a cause of action based on the Investment Company Act, and therefore demand was not required. $334 \mathrm{~F} .2 \mathrm{~d}$ at 819 .

Levitt does not mean that federal courts should ignore state rules on demand on shareholders whenever the cause of action is based on a federal statute. The opinion suggests that if the number of shareholders were small, demand would be required even if a negative vote by shareholders would bar minority shareholders from pursuing the claim. Id. at $818 \mathrm{n} .2$. The decision is limited to situations where demand would involve prohibitive expense and would not result in an "informed decision by the majority." Id. at 818 . The underlying assumption of Levitt is that federal courts will not follow state law if the state rules unreasonably frustrate shareholder derivative actions based on federal statutes. The holding of Levitt on the choice of law problem finds support in those cases which have held that shareholders need not meet the requirements of state security-for-expenses laws in derivative actions based on federal statutes. E.g., J.I. Case Co. v. Borak, 377 U.S. 426, 434-35 (1964) (dictum); McClure v. Borne Chem. Co., 292 F.2d 824 (3d Cir.), cert. denied, 368 U.S. 939 (1961); Fielding v. Allen, 181 F.2d 163 (2d Cir.) cert. denied, 340 U.S. 817 (1950). See Dykstra, supra note 3, at 84-88.

Levitt has had a mixed reception in the federal courts. Compare Jannes v. Microwave Communications, Inc., 57 F.R.D. 18 (N.D. III. 1972) (federal law applies to whether demand on shareholders is necessary in a federal securities action), with Jones v. Equitable Life Assurance Soc'y, 409 F. Supp. 370 (S.D.N.Y. 1975) (state law controls whether demand on shareholders is necessary in an action under the Investment Company Act). In In re Kauffman Mut. Fund Actions, 56 F.R.D. 128 (D. Mass. 1972), aff'd on other grounds, 479 F.2d 257 (1st Cir.), cert. denied, 414 U.S. 857 (1973), the plaintiff brought a derivative action under the antitrust laws against a mutual fund and its investment advisor. The plaintiff argued that demand on shareholders was unnecessary because there were over 300,000 shareholders to be contacted, $i d$. at 139 , a far greater number than the 48,000 found too large to require demand in Levitt. The court, however, held that while Levitt was controlling in actions under the Investment Company Act, demand on shareholders was required in actions under the antitrust laws. Id. at 139-40. The court in Levitt itself made this distinction. $334 \mathrm{~F} .2 \mathrm{~d}$ at $820 \mathrm{n} .5$. However, there is no logical basis for distinguishing between the Investment Company Act and the antitrust laws. While the Supreme Court in United Copper Sec. Co. v. Amalgamated Copper Co., 244 U.S. 261 (1917), stated that demand on shareholders was necessary in antitrust actions, it did not alter the conditional rule of Hawes v. Oakland, 104 U.S. 450, 461 (1882), that demand could be excused where it would be unreasonable to require it. The existence of over 300,000 shareholders seems a clear indication that requiring demand would be unreasonable. 
The weakest arguments for requiring demand are that the other shareholders can join in the action or put pressure on the directors to bring suit. It is difficult to imagine what is gained, other than moral support, by having additional shareholders join the action. ${ }^{132}$ At best, the result is that after the plaintiffs have expended considerable resources in making demand, the derivative suit will be larger. ${ }^{133}$ Similarly, requiring demand so that the majority shareholders may instruct the directors to bring suit serves little purpose. Such a request by the shareholders has no binding authority on the directors. ${ }^{34}$ Moreover, the directors, with their greater access to information and counsel, may have justifiably concluded that it would not be in the best interests of the corporation to sue.

Forcing the complaining shareholders to make demand on the other shareholders to remove the present board of directors and elect a new one pledged to initiating suit also involves considerable difficulty. ${ }^{135}$ The advantage of requiring demand for this purpose is that, if successful, the suit would be prosecuted by the directors rather than by the shareholders. A campaign to elect new directors, however, might require an expensive proxy fight and cause great delay, which could be fatal to the successful prosecution of the action. If the insurgents were unsuccessful in removing the directors, as is likely if the corporation were otherwise prosperous, their expenses probably would not be reimbursed. ${ }^{136}$ In cases involving closely held corporations, however, demand on the other shareholders to elect new directors might be required since the advantage of having the suit brought by the directors of the corporation would outweigh the minimal inconvenience to the complaining shareholders of making demand. ${ }^{137}$

The ratification theory is unsound, therefore because it overlooks several other forms of remedial shareholder action. However, this theory has the advantage of limiting the number of situations

${ }^{132}$ See, e.g., Mayer v. Adams, 37 Del. Ch. 298, 141 A.2d 458 (Sup. Ct. 1958).

130 One commentator has argued that the advantage of this type of demand is that it gives the majority shareholders the opportunity to prosecute the suit. See Demand on Directors, supra note 28 , at 751. The weakness of this argument is that it is the attorney, rather than the shareholders, who actually controls the litigation. See Dam, Class Actions: Efficiency, Compensation, Deterrence, and Conflict of Interest, 4 J. LEGaL Stud. 47, 56-61 (1975).

134 E.g., Gottesman v. General Motors Corp., 268 F.2d 194, 197 (2d Cir. 1959); Continental Sec. Co. v. Belmont, 206 N.Y. 7, 16-17, 99 N.E. 138, 141-42 (1912).

${ }_{135}$ E.g., Mayer v. Adams, 37 Del. Ch. 298, 303, 141 A.2d 458, 461 (Sup. Ct. 1958); Continental Sec. Co. v. Belmont, 206 N.Y. 7, 16-17, 99 N.E. 138, 141-42 (1912).

134 Rosenfeld v. Fairchild Engine \& Airplane Corp., 309 N.Y. 168, 128 N.E.2d 291 (1955).

13 Demand on Directors, supra note 28, at 750-51. 
where demand is unrealistically required. ${ }^{138} \mathrm{~A}$ more straightforward approach for the courts would be to excuse the failure to make demand on shareholders, not because the alleged wrong is nonratifiable, but because requiring demand would be unrealistic and impractical.

3. Undue Expense or Delay. One of the major problems with demand on shareholders is that the mechanics of making demand may involve prohibitive expense or delay. Where the delay would jeopardize the cause of action because of the statute of limitations or result in irreparable harm to the corporation, courts have generally excused the failure to make demand. ${ }^{139}$ However, courts have been less sympathetic to the financial hardship that making demand imposes on complaining shareholders. Although some courts have not required demand when the plaintiffs have alleged that the great number and dispersion of shareholders made demand financially unfeasible, ${ }^{140}$ other courts have stubbornly insisted on the requirement. ${ }^{141}$ In Saigh v. Busch, ${ }^{142}$ for example, the court required a demand on shareholders even though there were 10,867 shareholders owning 4,816,218 shares. ${ }^{143}$

A related problem occurs when the plaintiffs wish to make demand but management wrongfully refuses to permit access to a list of the corporation's shareholders. The courts have reached conflicting results in this situation; some hold that withholding access is sufficient to excuse the failure to make demand, ${ }^{144}$ while others require the plaintiffs to seek judicial action to secure shareholder lists and then make demand. ${ }^{145}$

${ }^{138}$ It has been suggested that the ratification theory rests upon a policy of deterrence rather than upon any conceptual limitations on the power of shareholders. See Note, The Nonratification Rule and the Demand Requirement: The Case for Limited Judicial Review, 63 Colum. L. REv. 1086, 1093 (1963).

${ }^{139}$ E.g., Interstate Refineries, Inc. v. Barry, 7 F.2d 548 (8th Cir. 1925); Campbell v. Loew's Inc., 36 Del. Ch. 533, 134 A.2d 565 (Ch. 1957).

${ }^{140}$ E.g., Levitt v. Johnson, 334 F.2d 815 (1st Cir. 1964), cert. denied, 379 U.S. 961 (1965); Gottesman v. General Motors Corp., 268 F.2d 194 (2d Cir. 1959); Weiss v. Sunasco, Inc., 316 F. Supp. 1197 (E.D. Pa. 1970); Berg v. Cincinnati, N. \& C. Ry., 56 F. Supp. 842 (E.D. Ky. 1944). This view has been recognized by the Supreme Court. In Delaware \& H. Co. v. Albany \& S.R.R., 213 U.S. 435, 452 (1909), the Court stated that the demand requirement was "intended to have practical operation, and to have that it must, as to its requirements, be given such play as to fit the conditions of different cases."

u E.g., Quirke v. St. Louis-S.F. Ry., 277 F.2d 705 (8th Cir.), cert. denied, 363 U.S. 845 (1960); Haffer v. Voit, 291 F.2d 704 (6th Cir.), cert. denied, 350 U.S. 832 (1955); Saigh v. Busch, 396 S.W.2d 9 (Mo. Ct. App. 1965), cert. denied, 384 U.S. 942 (1966).

it2 396 S.W.2d 9 (Mo. Ct. App. 1965), cert. denied, 384 U.S. 942 (1966).

${ }_{113}$ "The size of the corporation and the delay and expense in circularizing stockholders widely scattered does not excuse the failure to seek action from the stockholders." Id. at 24. IH E.g., Escoett v. Aldecress Country Club, 16 N.J. 438, 109 A.2d 277 (1954).

145 E.g., Bell v. Arnold, 175 Colo. 277, 487 P.2d 545 (1971). 
Requiring demand when it involves staggering expense can be explained only by judicial hostility to the derivative suit. Derivative actions can doubtless be abused by unscrupulous shareholders and attorneys who bring suits solely for their settlement value. Derivative actions, however, can also serve important functions: minority shareholders can serve as "needed policemen,"146 who uncover wrongdoing, pursue it publicly, and force directors and third parties to account for injuries inflicted on corporations. ${ }^{147}$ Forcing shareholders to expend huge sums in making demand deters not only strike suits but also the minority shareholders' role as useful gadflies. In light of the salutary effects that a derivative suit can have, demand on shareholders should not be required when the attendant costs are unreasonable. ${ }^{148}$

\section{The Problem of Standing to Sue After Intracorporate Remedies Have Been Exhausted}

In addition to exhausting intracorporate remedies, complaining shareholders must also demonstrate that they have standing to sue. ${ }^{149}$ To establish standing, the shareholders must demonstrate that the decision by the directors or the majority of shareholders against instituting suit should not be respected by a court. This comment will now analyze the nature of the standing requirement, what types of actions stockholders may bring, and, finally, the recent trend of courts to grant separate hearings on the question of standing to sue. A later section will explore the effect of a negative shareholder vote on the standing of a plaintiff to maintain a derivative action. ${ }^{150}$

\section{A. The Nature of the Standing Requirement}

Although some cases suggest that once the exhaustion requirement has been satisfied, either by a refusal by the corporation to act after demand or by a determination that demand is not required, shareholders may bring a derivative action, ${ }^{151}$ the better view is that shareholders may not maintain a derivative action until they have

is Dykstra, supra note 3 , at 78.

I47 See Pomerantz v. Clark, 101 F. Supp. 341 (D. Mass. 1951).

$1+\pi$ This is particularly true since there are alternative means of preventing strike suits. See note 5 supra.

1" For a discussion of the meaning of "standing" in the derivative action context, see note 5 supra.

${ }^{150}$ See text and notes at notes 200-16 infra.

15i See, e.g., Papilsky v. Berndt, 503 F.2d 554, 556 (2d Cir.), cert. denied, 419 U.S. 1048 (1974). 
demonstrated their standing to sue. ${ }^{152}$ Whether or not a corporation shall seek to enforce a cause of action is, like other business questions, ordinarily a matter of internal management left to the discretion of the board of directors. ${ }^{153}$ The directors are not obligated to pursue all causes of action and may justifiably waive a legal right vested in the corporation in the belief that the corporation's best interests will be served by not litigating. ${ }^{154}$ The directors are presumed to act honestly and, absent unusual circumstances, ${ }^{155}$ their decision not to sue will be final. ${ }^{156}$ Unless an equitable basis for interference is shown, stockholders have "no more right to challenge by a derivative suit a decision by the board of directors not to sue than to so challenge any other decision by the board."157 Otherwise, litigious shareholders, no matter how small their holdings, could usurp the authority properly delegated to the board by bringing a derivative action after the board had determined that litigation

152 The standing requirement has been described as the "sine qua non of the stockholder's derivative right to sue." Stadin v. Union Elec. Co., 309 F.2d 912 (8th Cir. 1962), cert. denied, 373 U.S. 915 (1963).

${ }_{153}$ United Copper Sec. Co. v. Amalgamated Copper Co., 244 U.S. 261, 263 (1917).

${ }^{25 t}$ Corbus v. Alaska Treadwell Gold Mining Co., 187 U.S. 455, 463 (1903). See also Hawes v. Oakland, 104 U.S. 450 , 456-57 (1882).

135 In Hawes v. Oakland, 104 U.S. 450, 460 (1882), the Supreme Court described the various situations in which shareholders may sue on behalf of the corporation.

Some action or threatened action of the managing board of directors or trustees of the corporation which is beyond the authority conferred on them by their charter or other source of organization;

Or such a fraudulent transaction completed or contemplated by the acting managers, in connection with some other party, or among themselves, or with other shareholders as will result in serious injury to the corporation, or to the interests of the other shareholders;

Or where the board of directors, or a majority of them, are acting for their own interest, in a manner destructive of the corporation itself, or of the rights of the other shareholders;

Or where the majority of shareholders themselves are oppressively and illegally pursuing a course in the name of the corporation, which is in violation of the rights of the other shareholders, and which can only be restrained by the aid of a court of equity. Recent cases have adopted this test for determining whether stockholders have standing to sue. See, e.g., Swanson v. Traer, 354 U.S. 114, 116 (1957); Gall v. Exxon Corp., 418 F. Supp. 508 (S.D.N.Y. 1976). For a similar formulation, see J.C.F. Holding Corp. v. General Gas \& Elec. Corp., 181 Misc. 283, 286, 46 N.Y.S.2d 605, 608 (Sup. Ct. 1943), aff'd mem., 267 App. Div. 863, 47 N.Y.S.2d 303 (1944).

${ }^{156}$ For cases dismissing derivative actions because the plaintiff shareholders had no standing to sue, see, e.g., United Copper Sec. Co. v. Amalgamated Copper Co., 244 U.S. 261 (1917); Corbus v. Alaska Treadwell Gold Mining Co., 187 U.S. 455 (1903); Hawes v. Oakland, 104 U.S. 450 (1882); Stadin v. Union Elec. Co., 309 F.2d 912 (8th Cir. 1962), cert. denied, 373 U.S. 915 (1963); Ash v. International Bus. Machs., Inc., 353 F.2d 491 (3d Cir. 1965), cert. denied, 384 U.S. 927 (1966); Swanson v. Traer, 249 F.2d 854 (7th Cir. 1957).

157 Swanson v. Traer, 249 F.2d 854, 859 (7th Cir. 1957). 
would be contrary to the best interests of the corporation. ${ }^{158}$

The requirement of standing to sue was clearly evidenced in Swanson v. Traer. ${ }^{159}$ In this case, the Supreme Court held that even though the directors were "definitely and distinctly opposed to the institution of litigation," 160 thus satisfying the exhaustion requirement, it was still necessary to inquire whether "this suit is of that exceptional character which stockholders may bring." 161 On remand, the Seventh Circuit emphasized that exhaustion of intracorporate remedies is not in itself sufficient ground for a dissident shareholder to maintain a derivative action..$^{162}$

While the necessity for standing is clear, there is little consensus on what types of suits shareholders have standing to bring. An examination of the various situations where shareholders have been allowed to bring derivative actions illustrates the confusion in the courts.

\section{B. The Situations Where Shareholders Have Standing to Sue}

While a refusal of the board of directors to act does not automatically entitle shareholders to bring a derivative suit, it does not necessarily preclude shareholder action. ${ }^{163}$ Shareholders are allowed to sue if there is proof that the board of directors has wrongfully refused to pursue a valid cause of action on behalf of the corporation. However, precisely what constitutes a wrongful refusal to sue is far from clear.

1. Control or Conflict of Interest. If the directors are either controlled by the alleged wrongdoer or interested in the transaction attacked ${ }^{164}$ to a degree which impairs the exercise of their business judgment, a refusal to sue by the directors has not barred a derivative action by the shareholders. ${ }^{165}$ Courts, however, should ensure that the directors are genuinely unable to exercise independent

158 Bernstein v. Mediobanca Banca di Credito Finanzario-Societa Per Azioni, 69 F.R.D. 592, 595 (S.D.N.Y. 1974).

130 354 U.S. 114 (1957).

160 Id. at 116.

1al Id.

162 249 F.2d 854, 858 (7th Cir. 1957).

105 Some courts have erroneously assumed that requiring demand on directors will somehow frustrate minority shareholders' ability to maintain a derivative action. E.g., In re Kauffman Mut. Fund Actions, 479 F.2d 257, 267 (1st Cir.), cert. denied, 414 U.S. 857 (1973). Other than requiring that a copy of the complaint be mailed to the directors, the demand on directors requirement does not affect the ability of shareholders to bring suit.

is See, e.g., Hawes v. Oakland, 104 U.S. 450, 460 (1882).

is E.g., Shulman v. Ritzenberg, 47 F.R.D. 202 (D.D.C. 1969). 
judgment before allowing shareholders to pursue the claim through a derivative suit. ${ }^{166}$

2. Participation in an Injurious or Illegal Transaction. This comment has argued that allegations of participation in an illegal or injurious transaction absent self-interest or bias should not be sufficient to excuse a failure to make demand on directors. ${ }^{167}$ After demand on directors has been made and refused, however, shareholders should be allowed to bring a derivative suit if a majority of the directors have participated in an injurious or illegal transaction. ${ }^{168}$ Shareholders have brought derivative actions to redress injuries to the corporation caused by excessive salaries, ${ }^{169}$ appropriation of corporate opportunities, ${ }^{170}$ improvident loans,,${ }^{171}$ improper sale of securities, ${ }^{172}$ and improper sale of control. ${ }^{173}$ Shareholders have also successfully challenged action by the directors that violated positive law. ${ }^{174}$

In many cases involving third party wrongdoers, the shareholders have argued that the decision by the directors not to sue should not be respected by the court because the directors themselves are liable for participation in the allegedly injurious or illegal transac-

${ }^{168}$ In Issner v. Aldrich, 254 F. Supp. 696 (D. Del. 1966), for example, the plaintiff brought a derivative action to redress injuries to the corporation arising from a past transaction. Demand was made on the directors but was refused. The plaintiff alleged that the decision of the directors not to sue should not bar a derivative action because the directors were controlled by the alleged wrongdoer. Id. at 699 . The court rejected this contention after determining that the board of directors was not so controlled. Id. at 701.

107 See text and notes at notes 63-75 supra.

${ }_{188}$ The shareholders must establish not only that the directors participated in the corporate transaction but also that the transaction was harmful to the corporation. In Hawes v. Oakland, 104 U.S. 450 (1882), a shareholder sought to enjoin the Contra Costa Co. from permitting the City of Oakland to take more water than it was legally entitled to without compensation. The Court dismissed the complaint, stating that "[i]t may be the exercise of the highest wisdom to let the city use the water in the matter complained of." Id. at 462.

${ }^{165}$ E.g., Smith v. Dunlap. 269 Ala. 97, 111 So.2d 1 (1959); Bachelder v. Brentwood Lanes, Inc., 369 Mich. 155, 119 N.W.2d 630 (1963).

-170 E.g., Higgins v. Shenago Pottery Co., 279 F.2d 46 (3d Cir.), cert. denied, 364 U.S. 899 (1960); Guth v. Loft, Inc., 23 Del. Ch. 255, 5 A.2d 503 (Sup. Ct. 1939).

17 E.g., Meltzer v. Atlantic Research Corp., 330 F.2d 946 (4th Cir.), cert. denied, 379 U.S. 841 (1964).

${ }^{172}$ Litwin v. Allen, 25 N.Y.S.2d 667 (S. Ct. 1940).

173 Perlman v. Feldman, 219 F.2d 173 (2d Cir.), cert. denied, 349 U.S. 952 (1955).

17 E.g., Rogers v. American Can Co., 305 F.2d 297 (3d Cir. 1962); Fanchon \& Marco, Inc. v. Paramount Pictures, Inc., 202 F.2d 731 (2d Cir. 1953). Shareholders may also bring derivative actions for breach of the fiduciary duty of care based on alleged violations of positive law. To prove a violation of fiduciary duty, however, shareholders must prove not only that the challenged activities violated positive law, but also that the defendants knew or should have known that the activities violated the law. E.g., Simon v. Socony-Vacuum Oil Co., 179 Misc. 202, 38 N.Y.S.2d 270 (Sup. Ct. 1942), aff'd mem., 267 App. Div. 890, 47 N.Y.S.2d 589 (1944). 
tion. ${ }^{175}$ If the shareholders can prove that the directors are personally liable, then the shareholders should be allowed to sue the third party wrongdoer as well as the directors.

3. Negligence in Failing to Assert a Clear Cause of Action. Some courts have allowed shareholders to sue when it appeared that the directors had unjustifiably refused to assert a clear cause of action. ${ }^{176}$ The majority of cases, however, have refused to consider the merits of the cause of action asserted by the shareholders on the ground that to do so would place the court in the position of substituting its judgment for that of the directors, which, if made in good faith, should not be disturbed. ${ }^{177}$ Refusing to allow shareholders to

175 See, e.g., Nussbacher v. Continental Ill. Nat'l Bank \& Trust Co., 518 F.2d 873 (7th Cir. 1975), cert. denied, 424 U.S. 928 (1976).

i7 In Epstein v. Schenck, 35 N.Y.S.2d 969 (Sup. Ct. 1939), for example, the plaintiff shareholder challenged a series of compensation payments to third parties as being excessive. Demand was made on the directors and refused. The directors claimed that since they had engaged in no fraud or misconduct, their decision not to sue was final. The court rejected this contention.

[T]here may be extreme cases where, notwithstanding the honest and deliberate determination of the governing body, judicial interference in a representative suit is justified. Where there is a clear cause of action, a refusal to enforce it may constitute a breach of trust on the part of the directors .... [ ] $\mathrm{t}$ is no answer on the part of directors that they deemed it inexpedient to bring the action.

35 N.Y.S.2d at 981. See also Groel v. United Elec. Co., 70 N.J. Eq. 616, 61 A. 1061 (Ch. 1905). One prominent commentator has endorsed the view that shareholders should be allowed to sue where the directors have failed to pursue a clear cause of action. "[W] here the right to recover is clear, it would seem that the management has no right to refuse to sue, and that where it does so refuse, the minority stockholders may sue in the place of the corporation." 13 W. Fletcher, Cyclopedia of the Law of Private Corporations $\$ 5822$, at 131 (rev. perm. ed. 1970).

Most of the cases concerning standing have ignored the question whether a failure to assert a clear cause of action is sufficient to confer standing on plaintiff shareholders. E.g., United Copper Sec. Co. v. Amalgamated Copper Co., 244 U.S. 261 (1917); Corbus v. Alaska Treadwell Gold Mining Co., 187 U.S. 455 (1903); Hawes v. Oakland, 104 U.S. 450 (1882). In none of these cases did the Court inquire into the merits of the controversy to determine whether the directors' decision not to sue was justified. However, these cases contain language that would allow shareholders to maintain derivative actions if directors failed to pursue a clear cause of action. In United Copper, for example, it was stated that courts can interfere with the decision of the directors not to sue when the directors "are guilty of misconduct equivalent to a breach of trust." 244 U.S. at 264 . Gross negligence in failing to assert a clear cause of action could constitute a breach of trust, but the Court did not follow this line of analysis.

in Courts may not interfere with the management of the corporation, unless there is bad faith, disregard of the relative rights of its members, or other action seriously threatening their property rights. This rule applies whether the mistake is due to error of fact or of law, or merely to bad business judgment. It applies, among other things, where the mistake alleged is the refusal to assert a seemingly clear cause of action . . . . Ashwander v. Tennessee Valley Authority, 297 U.S. 288, 343 (1935) (Brandeis, J., concurring). See also Ash v. International Bus. Machs., Inc., 353 F.2d 491, 493 (3d Cir. 1965), cert. denied, 384 U.S. 927 (1966); Lasker v. Burks, 404 F. Supp. 1172, 1180 (S.D.N.Y. 1975); 
sue when the directors inexcusably fail to pursue a clear cause of action, albeit in good faith, is inconsistent with the notion that directors owe the corporation a fiduciary duty of care that logically should extend to a decision not to sue. If shareholders are permitted to sue when the directors breach their fiduciary duty of loyalty by being interested in the transaction attacked, it is anomalous to prohibit suit when the directors breach their fiduciary duty of care. ${ }^{178}$

This analysis does not suggest that the directors must enforce every cause of action that the corporation might arguably possess. Directors should consider the likelihood of success of the proposed litigation, the direct and indirect $\operatorname{costs}^{179}$ of such litigation measured against the probable recovery, and the likelihood of commercial disadvantage arising from the impairment of friendly commercial relations with the defendants. ${ }^{180}$ Although courts should be reluctant to interfere with the internal affairs of a corporation, complaining shareholders should be allowed to maintain a derivative action where the corporate claim is clear, the costs of litigation are relatively small in relation to the probable recovery, and a lawsuit would not overly disrupt the commercial relations of the corporation.

4. Failure to Pursue a Constitutional Claim. A decision by the board of directors not to pursue a constitutional claim has been treated differently than a similar decision concerning a nonconstitu-

Bernstein v. Mediobanca Banca di Credito Finanzio-Societa Per Azioni, 69 F.R.D. 592, 596 (S.D.N.Y. 1974).

${ }^{178}$ It could be argued that if the directors inexcusably fail to sue an alleged wrongdoer, the shareholders should be relegated to a suit against the directors for breach of their fiduciary duty of care. In such a case, the measure of damages would be the amount that could have been recovered from the alleged wrongdoer. At least one case has allowed shareholders to sue directors for failure to pursue a clear cause of action against a third party. Harris v. Pearsall, 116 Misc. 366, 190 N.Y.S. 61 (Sup. Ct. 1921), appeal dismissed, 202 App. Div. 785, 194 N.Y.S. 942 (1922). However, this approach has several problems. First, it is not helpful in explaining the inconsistency of allowing derivative actions against alleged wrongdoers when directors breach their fiduciary duty of loyalty. If suits against directors should be the exclusive remedy for breaches of the duty of care, the same arguments can be made for making suits against directors the exclusive remedy for breaches of the duty of loyalty. Second, there is a certain harshness in forcing the directors to pay for the damage caused by an alleged wrongdoer; for example, if the wrongdoer commits an antitrust violation that results in a $\$ 20,000,000$ loss to the corporation, it seems unjust to require the directors to pay this sum, even assuming that they had the financial resources to do so. Finally, there are legal and factual issues incapable of adequate resolution in a suit solely against the directors: questions such as whether the alleged wrongdoer was actually liable, whether any affirmative defenses were available, and the amount of damages.

${ }^{179}$ Indirect costs include unfavorable publicity concerning the corporation and the loss of key employees. Demand on Directors, supra note 28, at 759-60 n.81.

${ }_{100}$ Blake, The Shareholders' Role in Antitrust Enforcement, 110 U. PA. L. REv. 143, 14849 (1961); Simon, Must We Sue? 17 Bus. Law. 888 (1962). 
tional cause of action. In the leading case of Ashwander $v$. Tennessee Valley Authority, ${ }^{181}$ stockholders of an Alabama electric utility brought a derivative action to enjoin the performance of a contract between the utility and the TVA because the TVA's activities were allegedly beyond the constitutional power of the federal government. The case presented the Supreme Court with its first opportunity to consider the constitutionality of the TVA's sales of electric power. While eight of the nine justices concurred in upholding the constitutionality of the sales, the majority split evenly on the question of whether the shareholders had standing to bring the action. The lead opinion of Chief Justice Hughes stated that the failure of the directors to resist an allegedly unconstitutional government demand was sufficient to confer the requisite standing upon the shareholders. ${ }^{182}$ In the concurring opinion, however, Justice Brandeis, applying the business judgment rule, concluded that the shareholders did not have standing since there was no showing of fraud or collusion. ${ }^{183}$

The lead opinion in Ashwander has left a legacy of confusion. No apparent reason exists why shareholders should be more able to pursue a constitutional claim than a statutory claim such as one involving an antitrust violation ${ }^{184}$ or illegal tax. ${ }^{185}$ If the corporation's best interests are served by dealing with the governmental instrumentality, shareholders should not be permitted to challenge the directors' decision not to sue. The wisdom of the Brandeis approach is perhaps evidenced by the narrowing of Ashwander in subsequent lower court decisions. ${ }^{186}$

1w: 297 U.S. 288 (1936).

$1 \times 2$ Id. at $318-23$.

1*3 Id. at 341-53.

Ixs United Copper Sec. Co. v. Amalgamated Copper Co., 244 U.S. 261 (1917).

1*s Corbus v. Alaska Treadwell Gold Mining Co., 187 U.S. 455 (1903).

${ }^{1 * 6}$ In Klotz v. Consolidated Edison Co., 386 F. Supp. 577 (S.D.N.Y. 1974), the plaintiff, a shareholder in Consolidated Edison $\mathrm{Co}$. (Con. Ed.), brought a derivative action against Con. Ed., the Public Service Commission of the State of New York, and the Finance Administrator of the City of New York. The gravamen of the complaint against the Public Service Commission was that it followed an unconstitutional confiscatory rate-making policy with respect to Con. Ed. The plaintiff also alleged that a tax levied against Con. Ed. by the City Finance Administration unconstitutionally deprived Con. Ed. of property without due process of law.

Not surprisingly, the plaintiff relied exclusively on the lead opinion in Ashwander to indicate that she had standing to maintain a derivative action. The court, however, distinguished Ashwander, stating that there the contention was that the government officials were acting pursuant to an unconstitutional statute, whereas in the case at bar the contention was that the government officials were acting under constitutional statutes but in an unconstitutional manner. $386 \mathrm{~F}$. Supp. at 583. It appears that courts are uncomfortable with the Ashwander doctrine and will interpret it whenever possible to conform to the general rule that courts will not substitute their judgment for that of the directors if the decision not to sue 
5. Refusal to Sue When Such Refusal Is Itself an Illegal Act. In Miller v. American Telephone \& Telegraph Co., ${ }^{187}$ the plaintiffs brought a derivative action against A.T.\&T. and its directors for injunctive relief to force A.T.\&T. to sue the Democratic National Committee for an outstanding debt from the 1968 convention. By failing to collect the debt, A.T.\&T. had allegedly made a contribution in violation of the federal prohibition on corporate campaign spending. ${ }^{188}$ The court stated that if the complaint had only alleged failure to pursue a corporate claim, the shareholders would have had no standing to attack the directors' decision not to sue. ${ }^{189}$ But because the decision not to sue was itself an allegedly illegal act, the court held that the business judgment rule was inapplicable and the shareholders had standing to sue. ${ }^{190}$ In the rare cases where the directors' decision not to sue is itself illegal, the directors are not exercising sound business judgment, and the shareholders should be allowed to maintain a derivative action.

\section{The Possibility of Separate Trials on the Standing Requirement}

Refusal by the board of directors to sue may constitute either a reasonable act of discretion or a breach of trust, depending on the circumstances. ${ }^{191}$ If the shareholders cannot demonstrate that the suit is of the "special character which stockholders may bring,"192 they have no standing to pursue the cause of action even if the corporation itself would have a valid cause of action. ${ }^{193}$ The standing requirement thus ensures that the shareholders cannot wrest control of the litigation from the corporation without an affirmative show-

was made reasonably and in good faith. See also Gall v. Exxon Corp., 418 F. Supp. 508 (S.D.N.Y. 1976).

${ }^{1 \times 7} 507$ F.2d 759 (3d Cir. 1974).

${ }^{1 \times 8}$ Id. at 761 .

Ix9 Id. at 762 .

190 Id.

191 W. Fletcher, Cyclopedia of the Law of Private Corporations $\S 5822$, at 131 (rev. perm. ed. 1970).

192 Swanson v. Traer, 249 F.2d 854, 860 (7th Cir. 1957).

${ }^{123}$ An analogous procedure is followed in suits by employees against employers after the union has refused to process a grievance. As in the relationship between shareholders and the board of directors, the union represents its employees. Ordinarily the union's decision not to prosecute a grievance is final, even if the employee has a valid grievance against his employer. If the union breaches its duty of fair representation (the equivalent of the fiduciary duty owed by directors) by refusing to process the grievance, the employee can sue his employer directly. In the event, however, that the employee fails to prove that the union breached its duty of fair representation, the suit is dismissed, no matter how meritorious the employee's claim against the employer. See Vaca v. Sipes, 386 U.S. 171 (1967). 
ing that the directors are incapable of exercising sound business judgment.

The protection afforded by the standing requirement is greatly compromised by the conventional procedure allowing the shareholders to proceed to a trial on both the issue of standing and the merits of the corporate claim against the alleged wrongdoer. ${ }^{194}$ This procedure allows complaining shareholders to engage in discovery and litigation on all issues before affirmatively demonstrating that they have standing to sue. Considerable wasteful litigation may result if during or after the trial the court determines that the shareholders lack standing and the suit is dismissed. The single trial procedure may also increase the possibility of strike suits.

Recognizing that standing is the threshold question in all derivative actions, several district courts have either ordered separate trials or limited discovery to the standing issue. ${ }^{195}$ Under the separate trial approach, litigation is limited to evaluating the business judgment of the directors, and a consideration of the corporate claim against the alleged wrongdoer is postponed. This procedure has the advantage of focusing on the question of the shareholders' right to bring the action before plunging into the merits of the complex corporate transaction underlying the claim. If the shareholders cannot prove that the directors are incapable of exercising sound business judgment, the suit will be dismissed.

The recent case of Gall $v$. Exxon Corp. ${ }^{196}$ provides an example of the usefulness of both separate discovery and a separate trial on the issue of standing. The plaintiff, a shareholder of Exxon, brought a derivative action against the directors for violations of the securities laws, waste, and breach of fiduciary duty. The complaint arose

196 In certain cases, the issues relevant to the standing issue and the corporate claim against the alleged wrongdoer will coincide. See note 198 infra.

135 Gall v. Exxon Corp., 418 F. Supp. 508 (S.D.N.Y. 1976); Nussbacher v. Continental Ill. Nat'l Bank \& Trust Co., 73 C 512 (N.D. Ill., April 22, 1976) (order granting separate trial); Lasker v. Burks, 404 F. Supp. 1172 (S.D.N.Y. 1975); Bernstein v. Mediobanca Banca di Credito Finanzio-Societa Per Azioni, 69 F.R.D. 592 (S.D.N.Y. 1974).

Separate trials are authorized by rule 42 (b) of the Federal Rules of Civil Procedure, which provides in relevant part:

Separate Trials. The court, in furtherance of convenience or to avoid prejudice, or when separate trials will be conducive to expedition and economy, may order a separate trial of any claim, cross-claim, counterclaim, or third-party claim, or of any separate issue or of any number of claims, cross-claims, counterclaims, third-party claims, or issues

FED. R. Crv. P. 42(b) (emphasis added). Implicit in rule 42(b) is the power to limit discovery to the segregated issues. Ellingson Timber Co. v. Great N. Ry., 424 F.2d 497, 499 (9th Cir.), cert. denied, 400 U.S. 957 (1970).

is 418 F. Supp. 508 (S.D.N.Y. 1976). 
out of the alleged payment of $\$ 59$ million to Italian political parties in order to secure favors and other allegedly illegal commitments. The directors of Exxon, pursuant to a provision in the by-laws, established a Special Committee on Litigation, composed of Exxon directors not involved in the transaction attacked, to investigate the claim. After a four-month investigation, the Committee concluded that it would be contrary to the best interests of the corporation to bring suit. The Committee directed Exxon to seek dismissal of the derivative action on the ground that the decision not to sue was made in the good faith business judgment of the directors of Exxon, and the shareholders therefore had no standing to sue. The plaintiff, however, challenged the disinterestedness and the bona fides of the Special Committee. The court directed that the plaintiff be allowed to test the independence of the Committee by discovery and, if necessary, at a plenary hearing. By limiting discovery to the propriety of the committee's decision not to sue, the court avoided simultaneous discovery and litigation of the difficult question whether the payments to the foreign officials were illegal. In the event that the decision not to sue was found to be untainted by bias, this issue would never be reached. ${ }^{197}$

Separate discovery and trials, however, will not be useful in every case. When there is substantial overlap between the issues relevant to the standing question and those relevant to the corporate claim against the alleged wrongdoer, ${ }^{198}$ a separate trial will normally not be warranted. ${ }^{199}$ But where the plaintiff's standing can be determined independently of the merits of the corporate claim, separate discovery and trials serve a useful function and should be used more often in shareholder derivative actions.

${ }^{197}$ A case very similar to Gall is Lasker v. Burks, 404 F. Supp. 1172 (S.D.N.Y. 1975). In Lasker, shareholders brought a derivative action under the securities laws against a mutual fund, several of its directors, and-its investment advisor. When alerted to the action, the board of directors appointed a disinterested group of directors to study the proposed action, who in turn retained Stanley Fuld, former Chief Judge of the New York Court of Appeals, to review the controversy. After Judge Fuld determined that the prosecution of the proposed action would be contrary to the best interests of the corporation, the directors moved to dismiss the derivative suit. The plaintiffs, however, disputed the independence and good faith of the minority directors appointed to study the claim. The court, recognizing that the shareholders' ability to sue was "dependent" upon the independence of the minority directors, limited discovery to this issue. $404 \mathrm{~F}$. Supp. at 1180.

${ }_{18 \mathrm{x}}$ There will be substantial overlap, for example, if the derivative suit is against all the directors for breach of their fiduciary duty. If, however, the directors' decision not to sue is attacked because the directors are controlled by the alleged wrongdoer or are biased because of an alleged conflict of interest, the standing question can be resolved independently of the merits of the corporate claim against the alleged wrongdoer.

1995 Moore's Federal Practice If 42.03, at $42-38$ to -40 (2d ed. 1976). 


\section{The Effect of a Negative Shareholder Vote}

If the directors' decision not to sue is made reasonably and in good faith, the minority shareholders have no standing to bring a derivative action. If, however, the directors either fail or are unable to exercise sound business judgment, the question remains whether minority shareholders can be deprived of standing by a negative shareholder vote. Under the business judgment theory, which requires demand on shareholders in order that the shareholders may determine whether the suit should be brought, a negative vote by shareholders should result in a dismissal of the derivative action. ${ }^{200}$ In the famous case of S. Solomon \& Sons Trust v. New England Theatres Operating Corp. ${ }^{201}$ the court held that the minority stockholders did not have the legal right to insist that suit be brought where a majority of disinterested stockholders acting reasonably and in good faith ${ }^{202}$ had voted against pursuing the action.

Other courts have rejected this view and have held that a negative vote by shareholders does not deprive minority shareholders of standing to maintain a derivative action. ${ }^{203}$ In jurisdictions which adhere to the ratification theory and require demand only when the wrong complained of is ratifiable, ${ }^{204}$ a negative vote by shareholders is a nullity if the underlying wrong is nonratifiable. ${ }^{205}$ Still other

200 Palley v. Baird, 356 Mass. 737, 254 N.E.2d 894 (1970); S. Solomont \& Sons Trust v. New England Theatres Operating Corp., 326 Mass. 99, 93 N.E.2d 241 (1950).

Some courts that have adopted the business judgment theory in requiring demand to be made on shareholders have refused to give effect to a negative vote by the shareholders. In American Life Ins. Co. v. Powell, 262 Ala. 560, 567, 80 So.2d 487, 492 (1954), the Supreme Court of Alabama held that demand on shareholders was necessary because they have "the final authority to determine whether or not it would be good business policy" to sue. In Smith v. Dunlap, 269 Ala. 97, 111 So.2d 1 (1959), the same court was faced with the question whether a negative vote by shareholders barred a derivative action. The court held that the shareholder could bring suit despite the adverse vote by a majority of the shareholders. Referring to its prior decision in Powell, the court stated that "[i]t was not the intention of this Court to hold that a majority of the stockholders could by ratifying fraudulent acts or by refusing to seek redress for such acts thereby preclude a minority stockholder from bringing suit." 269 Ala. at 103,111 So.2d at 6.

201326 Mass. 99, 93 N.E.2d 241 (1950).

${ }^{202}$ Id. at $114-15,93$ N.E. $2 d$ at 249 . Some commentators have suggested that the requirement that the shareholders act reasonably and in good faith means that the court must conduct a limited review of the merits of the plaintiff's claim. See Note, The Nonratification Rule and the Demand Requirement: The Case for Limited Judicial Review, 63 CoLum. L. Rev. 1086, 1099 (1963).

${ }^{203}$ E.g., Rogers v. American Can Co., 305 F.2d 297 (3d Cir. 1962); Gottlieb v. McKee, 34 Del. Ch. 537, 107 A.2d 240 (Ch. 1954); Siegman v. Electric Vehicle Co., 72 N.J. Eq. 403, 65 A. 910 (1907); Pollitz v. Wabash R.R., 207 N.Y. 113, 100 N.E. 721 (1912).

${ }_{204}$ See text and notes at notes 99-102 supra.

${ }^{205}$ Gottlieb v. McKee, 34 Del. Ch. 537, 107 A.2d 240 (Ch. 1954); Siegman v. Electric Vehicle Co., 72 N.J. Eq. 403, 65 A. 910 (1907); Pollitz v. Wabash R.R., 207 N.Y. 113, 100 N.E. 
cases have held that a negative vote by the majority of shareholders does not preclude complaining shareholders from bringing suit without relying on the nonratifiability of the underlying wrong. ${ }^{206}$ In Rogers v. American Can Co., ${ }^{207}$ the plaintiff brought a derivative action against his corporation, the members of its board of directors, and a second corporation for various antitrust violations. ${ }^{208}$ No demand on the directors was necessary since they were disqualified from exercising business judgment whether to sue by their illegal involvement in the transaction attacked. The plaintiff made a demand on the shareholders that was overwhelmingly rejected..$^{209}$ The shareholders also reelected the individual defendants as directors. ${ }^{210}$ The question before the court was whether the plaintiff had standing to bring the action in light of the adverse vote by an independent majority of shareholders. ${ }^{211}$ The District Court had concluded that the vote was an attempted ratification of a nonratifiable act rather than an exercise of business judgment not to sue and therefore did not deprive the shareholder of standing. ${ }^{212}$ The Third Circuit affirmed, ${ }^{213}$ but held that even if the negative vote of the shareholders was an expression of business judgment not to sue, this collective judgment had to yield to the right of a minority shareholder to press charges of violations of positive law. ${ }^{214}$

Two justifications, therefore, have been advanced for allowing shareholders to maintain a derivative action despite a negative vote by the majority shareholders-the nonratifiability of the alleged wrong and the right of minority shareholders to expose violations of positive law. Neither justification is persuasive. If the directors are disqualified from exercising business judgment, the shareholders are the only corporate organ available to determine whether bringing suit is in the best interest of the corporation. Labeling an underlying wrong as nonratifiable should not deprive shareholders of this power.

721 (1912). Technically, jurisdictions that adhere to the ratification theory do not require demand on shareholders where the underlying wrong is nonratifiable. However, the complaining shareholders may voluntarily make demand even when it is not required.

${ }^{206}$ E.g., Rogers v. American Can Co., 305 F.2d 297 (3d Cir. 1962).

207 Id.

20x Id. at 298-303.

${ }^{209}$ Id. at 300.

${ }^{210}$ Id.

211 Id. at 303 .

${ }^{212} 187$ F. Supp. 532 (D.N.J. 1960), aff'd, 305 F.2d 297 (3d Cir. 1962).

${ }_{213} 305$ F.2d 297 (3d Cir. 1962).

${ }^{21 s}$ Id. at 317. In Levitt v. Johnson, 334 F.2d 815, 818 n.2 (1st Cir. 1964), the court assumed but did not decide that a negative vote by shareholders could bar a derivative suit. The court acknowledged its disagreement with the Rogers holding. 
Disregarding a negative vote of the shareholders because of the right of minority shareholders to expose violations of positive law is no more convincing. The directors are not obligated to pursue every cause of action, even those based on alleged antitrust violations. ${ }^{215}$ The only difference between these cases and Rogers is that the directors in Rogers were disqualified from exercising business judgment. Once it is acknowledged, however, that it is not in the best interests of a corporation to sue for every alleged cause of action, it is unfair to allow minority shareholders to thrust the corporation into protracted and costly litigation when a majority of the shareholders disapprove of the action. The corporation should not lose its discretion whether or not to sue because the directors are disqualified from exercising sound business judgment, particularly when a disinterested majority of the shareholders, the true equitable owners of the corporation, votes against bringing suit. If the shareholders made an informed and disinterested choice whether the suit should be brought, ${ }^{216}$ their negative vote should deprive minority shareholders of standing to sue.

\section{ConcLusion}

This comment has analyzed the requirements of exhaustion of intracorporate remedies and standing to sue. To exhaust intracorporate remedies, a shareholder must make demand on both directors and shareholders as required by rule 23.1. Demand on directors allows the directors an opportunity to occupy their normal role in managing the corporation yet imposes little hardship on shareholders. Demand on directors should be required, therefore, if there is any possibility that the directors will take remedial action in response to the demand.

The demand on shareholders requirement, by contrast, does not place the suit in the control of those who normally manage the corporation and can be prohibitively expensive. Demand on shareholders should be required only when the number of shareholders is relatively small. The ratifiability of the wrong attacked should not affect whether demand on shareholders is required; shareholders should have the opportunity to exercise their business judgment on

26 United Copper Sec. Co. v. Amalgamated Copper Co., 244 U.S. 261 (1917); Ash v. International Bus. Machs., Inc., 353 F.2d 491 (3d Cir. 1965), cert. denied, 384 U.S. 927 (1966); Post v. Buck's Stove \& Range Co., 200 F. 918 (8th Cir. 1912).

${ }^{215}$ The rationale underlying the holding in Rogers may have been that the court did not believe the shareholders' decision not to sue was informed. The shareholders were forced to make the decision on the basis of a 250-word proxy statement. $305 \mathrm{~F} .2 \mathrm{~d}$ at 299-300. 
whether the suit should be brought.

After the minority shareholders have satisfied the demand requirements of rule 23.1, they must still establish standing to sue. The standing requirement is not embodied in the Federal Rules of Civil Procedure but is based on the premise that a shareholder cannot bring an action unless the corporation's refusal to sue was wrongful. Directors are not obligated to pursue all causes of action which the corporation might arguably possess. In order successfully to maintain a derivative action, therefore; a shareholder must prove not only that the corporation has a valid claim against the alleged wrongdoer, but that the corporation's refusal to pursue the claim is wrongful. If the shareholder cannot prove that the decision not to sue was wrongful, the suit will be dismissed even if the corporation has a valid claim against the alleged wrongdoer. Recognizing that standing is the threshold problem in derivative suits, several courts have recently ordered separate trials and discovery on the standing issue.

In the event that the directors are disqualified from exercising sound business judgment, minority shareholders should be precluded from maintaining a derivative action by a negative vote of a majority of the shareholders. Neither the nonratifiability of the alleged wrong nor the right of minority shareholders to expose violations of positive law is a sufficient ground to allow a shareholder to bring suit against the will of an informed and disinterested majority.

Daniel R. Fischel 